\title{
A New Supported Manganese-Based Coordination Complex as a Nano-Catalyst for the Synthesis of Indazolophthalazinetriones and Investigation of Its Antibacterial Activity
}

maryam ariannezhad ( $\square$ mary.ariannezhad@yahoo.com )

Bu Ali Sina University davood habibi

Bu Ali Sina University somayyeh heydari

Bu Ali Sina University vahideh khorram Abadi Bu Ali Sina University

\section{Research Article}

Keywords: Aldehyde, Dimedone, Indazolophthalazinetrione, Phthalhydrazide, The Mn supported nanocatalyst

Posted Date: May 17th, 2021

DOI: https://doi.org/10.21203/rs.3.rs-510455/v1

License: (c) (1) This work is licensed under a Creative Commons Attribution 4.0 International License. Read Full License 


\section{Abstract}

A new magnetic supported manganese-based coordination complex $\left(\mathrm{Fe}_{3} \mathrm{O}_{4} @ \mathrm{SiO}_{2} @ \mathrm{CPTMS} @ \mathrm{MBOL} @\right.$ $\mathrm{Mn}$ ) was prepared in consecutive stages, characterized via various techniques (VSM, SEM, TEM, XRD, FTIR, EDX, TG-DTA and ICP) and used as a capable nano-catalyst for the fast and green synthesis of divers $2 H$-indazolo[2,1-b]phthalazine-1,6,11(13H)-triones in a simple and efficient procedure from the one pot three-component condensation reaction of aldehydes, dimedone and phthalhydrazide in refluxed ethanol in excellent yields and fast reaction times. The Mn catalyst can be recycled and reused without notable loss of the catalytic activity. Also, the antibacterial properties of the Mn supported nano-catalyst were studied against a number of gram-positive and gram-negative bacterial strains.

\section{Introduction}

Phthalazine derivatives have an important role in heterocyclic compounds that have received terrific interests in the field of pharmaceutical and biological activities that leads to clinical application ${ }^{1}$ such as antifungal ${ }^{2}$, anti-inflammatory, ${ }^{3}$ anticonvulsant, ${ }^{4}$ anticancer, ${ }^{5}$ cardiotonic. ${ }^{6}$ In addition, these compounds represents specific optical properties. ${ }^{7}$

Multi-component reactions (MCRs) are notable mechanism for preparation of wide variety of organic compounds via better efficiency in one step with at least three or more starting materials. ${ }^{8}$ Using a large number of different type of catalysts which accelerate or proceed the reaction in smooth condition have been extensively developed for these reactions. ${ }^{9-11}$ Several synthetic routes have been reported for the synthesis of Phthalazine derivatives such as one-pot three- or four- component condensation reactions. ${ }^{12-16}$ For example, $\mathrm{Fe}_{3} \mathrm{O}_{4} @$ @ys $-\mathrm{SO}_{3} \mathrm{H}$ was used by Kefayati and coworker as a catalyst for the one-pot three-component condensation of aromatic aldehydes, phthalhydrazide and 1,3-dicarbonyl compounds for the synthesis of $2 H$-indazolo[2,1-b]phthalazinetriones derivatives in ethanol at refluxed condition. ${ }^{17}$ Shirini and coworkers applied $[\mathrm{PVPH}] \mathrm{ClO}_{4}$ as an efficient and reusable solid acid polymeric catalyst for the synthesis of $2 H$-indazolo[2,1-b]phthalazine- triones in the same way of using initial regents through the one-pot reaction at $100^{\circ} \mathrm{C}$ in solvent-free conditions. ${ }^{18}$ Heirati and coworkers investigated implementation of O-sulfonic acid poly(4-vinylpyrrolidonium) chloride as an effective catalyst for the same synthesis at $80^{\circ} \mathrm{C}$ in solvent-free conditions. ${ }^{19}$ Rostamnia and co-worker synthesized a series of $1 H$-indazolo[1,2-b]phthalazine-1,6,11-triones by similar regents and using the $\mathrm{Fe}_{3} \mathrm{O}_{4} @ \mathrm{GO}-\mathrm{Pr}-\mathrm{SO}_{3} \mathrm{H}$ catalyst in refluxed ethanol. ${ }^{20} 5$-sulphosalicylic acid was used by Karhale and coworkers as an organocatalyst catalyst for the one-pot synthesis of $2 H$-indazolo[2,1-

$b$ phthalazinetriones from the previous substrates. ${ }^{21}$ Varghese and coworkers through a noticeable method synthesized $2 H$-indazolo[2,1-b]phthalazine-1,6, 11(13H)-triones by similar regents in the presence of iodine under ultrasonic irradiation. ${ }^{22}$ Mosaddegh and coworkers succeeded to synthesize phthalazinetriones derivatives through a rapid, one-pot, four-component route by using $\mathrm{Ce}\left(\mathrm{SO}_{4}\right)_{2} \cdot 4 \mathrm{H}_{2} \mathrm{O}$ at $125^{\circ} \mathrm{C}$ and under solvent free condition. ${ }^{23}$ However, some methods suffer from some limitations such as 
tedious workup procedures, using corrosive catalysts, low product yields, long reaction times, formation of side products and difficulties in recovery of catalysts. ${ }^{24}$

Due to concerns on environmental issues different strategies were applied to reduce side- effects of chemical industries, for instance using solvent-free techniques, eco-friendly materials, ultrasound or microwave methods and finally recyclable catalysts. ${ }^{25}$ In recent years the application of magnetic nanoparticles (MNPs) according to the super magnetic property and facile separation from reactions media, high surface area, low toxicity, biocompatibility, good stability, low cost has obtained noticeable regards for chemists using as catalysts in chemical reactions. Moreover, MNPs can be functionalized completely via proper surface modifications. Based on mentioned properties, many MNPs-supported catalysts have been effectively applied for improving a large number of chemical reactions. ${ }^{26,27}$ Among the heterogeneous catalysts, the magnetic supported metal complexes have special places, ${ }^{28}$ so we would like to announce the synthesis a novel Mn supported nano-catalyst $\left(\mathrm{Fe}_{3} \mathrm{O}_{4} @ \mathrm{SiO}_{2} @ \mathrm{CPTMS} @ M B O L @ M n\right)$ in consecutive stages (Scheme 1).

Then, the Mn supported nano-catalyst was characterized by various techniques (VSM, SEM, TEM, XRD, FT-IR, EDX, TG-DTA and ICP) and used as a capable nano-catalyst for the synthesis of divers $2 \mathrm{H}$ indazolo[2,1-b]phthalazine-1,6,11(13H)-triones in a simple and efficient procedure from the one pot threecomponent condensation reaction of aldehydes, dimedone and phthalhydrazide in refluxed ethanol in good yields and fast reaction times (Scheme 2).

\section{Results And Discussion}

\subsection{Characterization of the Mn supported nano-catalyst}

Structure of the Mn supported nano-catalyst was approved utilizing the FT-IR, ICP, VSM, XRD, EDX, TEM, SEM, and TG-DTA.

\subsubsection{ICP analysis of the Mn supported nano-catalyst}

The Mn content in $\mathrm{Fe}_{3} \mathrm{O}_{4} @ \mathrm{SiO}_{2} @ \mathrm{CPTMS} @ M B O L @ M n$ was achieved about 0.27\% by The ICP analysis.

\subsubsection{FT-IR spectroscopy of the Mn supported nano-catalyst}

Figure 1 illustrates the FT-IR spectra for each step of preparation of nano catalyst that includes $A) \mathrm{Fe}_{3} \mathrm{O}_{4}$ MNPs, B) Fe $\mathrm{F}_{3} \mathrm{O}_{4} @ \mathrm{SiO}_{2}$, C) $\left.\mathrm{Fe}_{3} \mathrm{O}_{4} @ \mathrm{SiO}_{2} @ \mathrm{CPTMS}, \mathrm{D}\right) \mathrm{Fe}_{3} \mathrm{O}_{4} @ \mathrm{SiO}_{2} @ \mathrm{CPTMS} @ M B O L$ and E) $\mathrm{Fe}_{3} \mathrm{O}_{4} @ \mathrm{SiO}_{2} @ \mathrm{CPTMS} @ M B O L @ M n . I n$ part A existence of stretching vibrations peak for $\mathrm{Fe}-\mathrm{O}$ is characteristic at about $578 \mathrm{~cm}^{-1}$. Appearing of a wide peak close by $1087 \mathrm{~cm}^{-1}$ in part $B$ indicates the coating of silica with magnetite nanoparticles. Part C exhibits a unique peak at about $583 \mathrm{~cm}^{-1}$ confirming the presence of the $\mathrm{C}-\mathrm{Cl}$ bond. Part $\mathbf{D}$ shows two newly discovered peaks at 1345 and 1664 $\mathrm{cm}^{-1}$ which are corresponded to the $\mathrm{C}-\mathrm{N}$ and $\mathrm{C}=\mathrm{N}$ bonds, respectively. Part $\mathrm{E}$ indicates a shift from 1664 
to $1602 \mathrm{~cm}^{-1}$ which could be in accordance of the new interaction of manganese with the nitrogen of the $\mathrm{C}=\mathrm{N}$ bond. Also at $408.93 \mathrm{~cm}^{-1}$ a weak peak was appeared in corresponding to the Mn-N band.

Therefore, comparison of the all IR spectra approved the successful formation of the Mn supported nanocatalyst.

\subsubsection{XRD analysis of the Mn supported nano-catalyst}

In order to evaluate the crystallographic structure of $\mathrm{Fe}_{3} \mathrm{O}_{4} @ \mathrm{SiO}_{2} @ \mathrm{CPTMS} @ M B O L @ M n$, the XRD analysis was carried out for $\mathrm{Fe}_{3} \mathrm{O}_{4} @ \mathrm{SiO}_{2}$ (grey, A), $\mathrm{Fe}_{3} \mathrm{O}_{4} @ \mathrm{SiO}_{2} @ \mathrm{CPTMS}$ (red, B),

$\mathrm{Fe}_{3} \mathrm{O}_{4} @ \mathrm{SiO}_{2} @ \mathrm{CPTMS} @ M B O L$ (blue, C) and $\mathrm{Fe}_{3} \mathrm{O}_{4} @ \mathrm{SiO}_{2} @ \mathrm{CPTMS} @ M B O L @ M n$ (green, D) and shown in Fig. 2. The diffraction peaks at $2 \theta=$ at $10,30,35,45,53,57$ and 63 approve the silica coated on the cubic spinel crystal planes of $\mathrm{Fe}_{3} \mathrm{O}_{4}$ effectively. The XRD pattern of $\mathrm{Fe}_{3} \mathrm{O}_{4} @ \mathrm{SiO}_{2} @ \mathrm{CPTMS} @ M B O L @ M$ indicates the crystalline nature of the nano catalyst at $2 \theta=30,35,39,43,56$ which responded to the Mn catalyst. Through Debye Scherrer formula the particle size was obtained about $34.68 \mathrm{~nm}$. In fact, due to the reduction of intensity the core-shell structure could be anticipated and the $\mathrm{Fe}_{3} \mathrm{O}_{4} \mathrm{MNPs}$ particles were coated with ligand profitably. ${ }^{29-31}$

\subsubsection{EDX analysis of the Mn supported nano-catalyst}

The elemental structure of the Mn supported nano-catalyst was disclosed by the EDX analysis (Fig. 3). The results ratified the existence of the predictable elements in the construction of the catalyst, including $\mathrm{C}, \mathrm{N}, \mathrm{O}, \mathrm{Si}, \mathrm{S}, \mathrm{Fe}$ and $\mathrm{Mn}$. Generally the sample will be usually coated with a very thin layer of gold that leads appearing of the Au peak in the EDX graph analysis, as well.

\subsubsection{SEM and TEM analysis of the Mn supported nano- catalyst}

In another evaluation, the morphology and size of the Mn supported nano-catalyst were determined by SEM and TEM images (Fig. 4-5). The spherical shape of the $\mathrm{Fe}_{3} \mathrm{O}_{4} @ \mathrm{SiO}_{2} @ C P T M S @ M B O L @ M n$ is conceived through the uniform nanometer-sized particles. In the SEM images, formation of sintered grains with the 35-47 nm size range was apparent. The core-shell structure of nano catalyst could be observed via TEM images. However, magneto static interactions of the particles could be the reason of some particle aggregations. At an exact scrutiny, according to distribution histograms (Fig. 6), the average sizes of the nanoparticles is anticipated between 19.1 and $29.7 \mathrm{~nm}$.

\subsubsection{Thermal properties of the Mn supported nano-catalyst}

The thermo-gravimetric analysis shows the thermal stability and decomposition behavior of the Mn supported nano-catalyst beyond heating (Fig. 6). As observed there are about four weight loss stages for the catalyst in the ranges of $100,185,300$, and $360 \otimes C$, respectively. The initial weight reduction at about

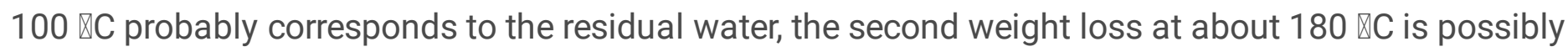

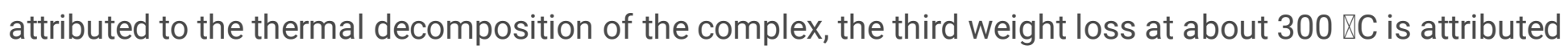


to the thermal decomposition of the two CPTMS and MBOL ligands, and the fourth weight reduction at

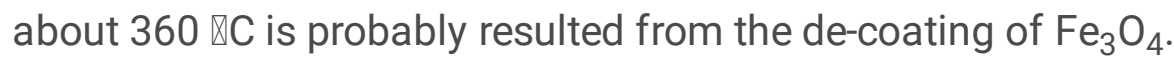

\subsubsection{VSM analysis of the Mn supported nano-catalyst}

Due to comparison of magnetic properties, the VSM analysis was performed for the five steps of preparing including A) $\mathrm{Fe}_{3} \mathrm{O}_{4}$ MNPs, B) $\mathrm{Fe}_{3} \mathrm{O}_{4} @ \mathrm{SiO}_{2}$, C) $\left.\mathrm{Fe}_{3} \mathrm{O}_{4} @ \mathrm{SiO}_{2}-\mathrm{CPTMS}, \mathrm{D}\right)$

$\mathrm{Fe}_{3} \mathrm{O}_{4} @ \mathrm{SiO}_{2} @ \mathrm{CPTMS} @ M B O L$ and E) $\mathrm{Fe}_{3} \mathrm{O}_{4} @ \mathrm{SiO}_{2} @ C P T M S @ M B O L @ M n$ (Fig. 7). Generally, all five steps of formation show magnetic possessions and a clear decrease from $A$ to $E(65,35,30,10$ and 4.35 $\mathrm{emu} / \mathrm{g}$, respectively) can be observed. In fact the dipolar-dipolar interactions reduce between the magnetic nanoparticles due to coating of $\mathrm{Fe}_{3} \mathrm{O}_{4}$ MNPs via different layers and complexation.

\section{Experimental}

\subsection{General}

All chemicals (starting materials, reagents, solvents, etc) were acquired from the chemical companies and used in the absence of additionally purification.

\subsection{Preparation of the Mn supported nano-catalyst}

The Mn supported nano-catalyst was prepared according to the procedure described. ${ }^{32}$

\subsection{General Procedure for the synthesis of indazolophthalazinetriones}

Phthalhydrazide ( $0.162 \mathrm{~g}, 1.0 \mathrm{mmole})$, dimedone ( $0.140 \mathrm{~g}, 1.0 \mathrm{mmole})$, an aldehyde derivative (1.0 mmole) and the Mn supported nano-catalyst $(20 \mathrm{mg})$ were mixed in ethanol $(5 \mathrm{~mL})$, stirred and heated at reflux condition in appropriate times which depends on the substrate (Table 2), and completion of the reaction was monitored with TLC. After cooling, the Mn supported nano-catalyst was separated by a super magnet, $\mathrm{H}_{2} \mathrm{O}(10 \mathrm{~mL})$ added, and a white precipitate filtered and recrystallized in EtOH.

\subsection{Optimization}

To obtain the best result, effects of different conditions were investigated for this reaction. The one-pot three-component condensations of phthalhydrazide (1.0 mmole), 4-methylbenz-aldehyde ( $1.0 \mathrm{mmole})$ and dimedone ( $1.0 \mathrm{mmole}$ ) was chosen as a model reaction in different reaction conditions (amount of the catalyst temperature and solvent). The best result was achieved with 1.0 mmole of 1:1:1 of benzaldehyde: dimedone: phthalhydrazide in presence of $20 \mathrm{mg}$ of the $\mathrm{Mn}$ supported nano-catalyst in EtOH at reflux condition (Table 1, entry 5). 
Table 1

Optimization of the reaction conditions

\begin{tabular}{|llllll|}
\hline Entry & Solvent & Catalyst $(\mathbf{m g})$ & Temperature $\left({ }^{\circ} \mathrm{C}\right)$ & Time $(\mathbf{m i n})$ & Yield (\%) \\
\hline $\mathbf{1}$ & $\mathrm{EtOH} / \mathrm{H}_{2} \mathrm{O}$ & 10 & 80 & 15 & 71 \\
\hline $\mathbf{2}$ & $\mathrm{EtOH} / \mathrm{H}_{2} \mathrm{O}$ & 20 & 80 & 15 & 82 \\
\hline $\mathbf{3}$ & $\mathrm{EtOH} / \mathrm{H}_{2} \mathrm{O}$ & 30 & 80 & 15 & 74 \\
\hline $\mathbf{4}$ & $\mathrm{EtOH} / \mathrm{H}_{2} \mathrm{O}$ & 40 & 80 & 15 & 74 \\
\hline $\mathbf{5}$ & $\mathrm{EtOH}$ & $\mathbf{2 0}$ & $\mathbf{8 0}$ & $\mathbf{1 5}$ & $\mathbf{9 0}$ \\
\hline $\mathbf{6}$ & $\mathrm{H} \mathrm{H}_{2} \mathrm{O}$ & 20 & 80 & 15 & 76 \\
\hline $\mathbf{7}$ & $\mathrm{Toluene}$ & 20 & 80 & 15 & 53 \\
\hline $\mathbf{8}$ & $\mathrm{DMF}$ & 20 & 80 & 15 & 49 \\
\hline $\mathbf{9}$ & $\mathrm{EtOH}$ & 20 & 60 & 15 & 72 \\
\hline $\mathbf{1 0}$ & EtOH & 20 & 40 & 15 & 37 \\
\hline $\mathbf{1 1}$ & EtOH & 20 & $\mathrm{rt}$ & 15 & 21 \\
\hline
\end{tabular}

Also, two additional reactions were performed under the optimum conditions as below:

1. The synthesis of indazolophthalazinetriones carried out in the absence of

$\mathrm{Fe}_{3} \mathrm{O}_{4} @ \mathrm{SiO}_{2} @ \mathrm{CPTMS} @ \mathrm{MBOL} @ M n$ :The reaction efficiency was very low (trace).

2. The reaction was done in the presence of $\left(\mathrm{Fe}_{3} \mathrm{O}_{4} @ \mathrm{SiO}_{2} @ \mathrm{CPTMS} @ \mathrm{MBOL}\right)$ and no product was observed.

\subsection{Synthesis of diverse indazolophthalazinetriones (2a-j)}

According to the optimization of model reaction, different indazolophthalazinetriones (2a-j) were synthesized from the one pot three-component condensation reaction of aldehydes, dimedone and phthalhydrazide in EtOH at reflux conditions in attendance of the Mn supported nano-catalyst with good to excellent yields in fast reaction times (Table 2).

\subsection{Characterization of the products}

All indazolophthalazinetriones were characterized and recognized by considering to their physical and spectroscopic analysis and comparing the reported in the literature. The structures of all products were confirmmed via their IR and NMR spectra (Supplementary data).

3,3-Dimethyl-13-phenyl-3,4-dihydro-1 H-indazolo[2,1,b]phthalazine-1,6,11(2H,13H)-trione (2a): mp 202-

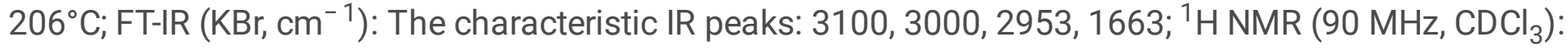


$\delta_{\mathrm{H}}=7.80-8.37(\mathrm{~m}, 4 \mathrm{H}), 7.26(\mathrm{~m}, 5 \mathrm{H}), 6.45(\mathrm{~s}, 1 \mathrm{H}), 3.30\left(\mathrm{~d}, 2 \mathrm{H}, \mathrm{CH}_{2}\right), 2.33\left(\mathrm{~s}, 2 \mathrm{H}, \mathrm{CH}_{2}\right), 1.22\left(\mathrm{~s}, 6 \mathrm{H}, 2 \mathrm{CH}_{3}\right)$.

${ }^{13} \mathrm{C} \mathrm{NMR}\left(75 \mathrm{MHz}, \mathrm{CDCl}_{3}\right): 28.7,34.7,38,5,65,77.5,118,127,127,127.7,128,128.6,128.7,128.8,128.9$, $129,133.5,134.5,136.3,150.8,154.2,156,192$.

13-(4-Chlorophenyl)-3,3-dimethyl-3,4-dihydro-1 H-indazolo[2,1-b]phthalazine-1,6,11(2H,13H)-trione (2b): mp 260-263 ${ }^{\circ} \mathrm{C}$; FT-IR $\left(\mathrm{KBr}, \mathrm{cm}^{-1}\right)$ : The characteristic IR peaks: 3100, 3000, 2957, $1660 ;{ }^{1} \mathrm{H}$ NMR $(90 \mathrm{MHz}$, $\left.\mathrm{CDCl}_{3}\right): \delta_{\mathrm{H}}=7.81-8.41(\mathrm{~m}, 4 \mathrm{H}), 7.32(\mathrm{~m}, 4 \mathrm{H}), 6.41(\mathrm{~s}, 1 \mathrm{H}), 3.30\left(\mathrm{~d}, 2 \mathrm{H}, \mathrm{CH}_{2}\right), 2.34\left(\mathrm{~s}, 2 \mathrm{H}, \mathrm{CH}_{2}\right), 1.21(\mathrm{~s}, 6 \mathrm{H}$, $\left.2 \mathrm{CH}_{3}\right) .{ }^{13} \mathrm{C} \mathrm{NMR}\left(75 \mathrm{MHz}, \mathrm{CDCl}_{3}\right): 28.5,34.4,38,50,61.3,77,118,127.7,128.2,129.2,134,151,154.3$, 192.

13-(4-Bromophenyl)-3,3-dimethyl-3,4-dihydro-1 H-indazolo[2,1-b]phthalazine-1,6,11(2H,13H)-trione (2c): mp 256-259 $\mathrm{C}$; FT-IR $\left(\mathrm{KBr}, \mathrm{cm}^{-1}\right)$ : The characteristic IR peaks: 3100, 3000, 2959, 1687, 1654; ${ }^{1} \mathrm{H}$ NMR (90 $\left.\mathrm{MHz}, \mathrm{CDCl}_{3}\right): \delta_{\mathrm{H}}=7.86-8.39(\mathrm{~m}, 4 \mathrm{H}), 7.23-7.35(\mathrm{~m}, 4 \mathrm{H}), 6.70(\mathrm{~s}, 1 \mathrm{H}), 3.23-3.45\left(\mathrm{~d}, 2 \mathrm{H}, \mathrm{CH}_{2}\right), 2.34(\mathrm{~s}, 2 \mathrm{H}$, $\left.\mathrm{CH}_{2}\right), 1.23\left(\mathrm{~s}, 6 \mathrm{H}, 2 \mathrm{CH}_{3}\right)$.

3,3-Dimethyl-13-(3-nitrophenyl)-3,4-dihydro-1 H-indazolo[2,1,b]phthalazine-1,6,11(2H,13H)-trione (2d): mp 267-270 ${ }^{\circ}$; FT-IR $\left(\mathrm{KBr}, \mathrm{cm}^{-1}\right)$ : The characteristic IR peaks: $3100,3000,2962,1661 ;{ }^{1} \mathrm{H} \mathrm{NMR}(300 \mathrm{MHz}$, $\left.\mathrm{CDCl}_{3}\right): \delta_{\mathrm{H}}=7.87-8.40(\mathrm{~m}, 4 \mathrm{H}), 6.52-7.59(\mathrm{~m}, 4 \mathrm{H}), 6.52(\mathrm{~s}, 1 \mathrm{H}), 3.24-3.47\left(\mathrm{dd}, 2 \mathrm{H}, \mathrm{CH}_{2}\right), 2.35(\mathrm{~s}, 2 \mathrm{H}$, $\left.\mathrm{CH}_{2}\right), 1.22\left(\mathrm{~s}, 6 \mathrm{H}, 2 \mathrm{CH}_{3}\right) .{ }^{13} \mathrm{C} \mathrm{NMR}\left(75 \mathrm{MHz}, \mathrm{CDCl}_{3}\right): 27.3,28.4,28.6,34.7,38,50.8,64,76.5,77,117$, 121.5, 123.7, 127.7, 128.2, 128.6, 129, 129.6, 134, 134.2, 134.7, 138.6, 148.5, 151.8, 154.6, 156, 192.

13-(2,4-Dichlorophenyl)-3,3-dimethyl-3,4-dihydro-1 H-indazolo[2,1- $b]$ phthalazine-1,6,11-(2H, $13 H$ )-trione (2e): $\mathrm{mp} 219-222^{\circ} \mathrm{C}$; FT-IR $\left(\mathrm{KBr}, \mathrm{cm}^{-1}\right)$ : The characteristic IR peaks: 3100, 3000, 2964, 2940, 1663; ${ }^{1} \mathrm{H}$ $\operatorname{NMR}\left(90 \mathrm{MHz}, \mathrm{CDCl}_{3}\right): \delta_{\mathrm{H}}=7.75-8.38(\mathrm{~m}, 4 \mathrm{H}), 7.13-7.26(\mathrm{~m}, 3 \mathrm{H}), 6.6(\mathrm{~s}, 1 \mathrm{H}), 3.3\left(\mathrm{~d}, 2 \mathrm{H}, \mathrm{CH}_{2}\right), 2.33(\mathrm{~s}, 2 \mathrm{H}$, $\left.\mathrm{CH}_{2}\right), 1.22\left(\mathrm{~s}, 6 \mathrm{H}, 2 \mathrm{CH}_{3}\right) .{ }^{13} \mathrm{C} \mathrm{NMR}\left(75 \mathrm{MHz}, \mathrm{CDCl}_{3}\right): 28.8,34.6,38,50.8,63.5,77,127.6,127.7,128,128.6$, $129,130.4,131.7,133.2,133.7,134.6,135,152,154.3,156,192$.

3,4-Dihydro-3,3-dimethyl-13-(4-methylphenyl)-2H-indazolo[2,1-b]phthalazine-1,6,11(13H)-trione (2f): $\mathrm{mp}$ 224-227 ${ }^{\circ} \mathrm{C}$; FT-IR $\left(\mathrm{KBr}, \mathrm{cm}^{-1}\right)$ : The characteristic IR peaks: 3100, 3000, 2924, 1687, $1655 ;{ }^{1} \mathrm{H}^{\mathrm{N} M R}(90$ $\left.\mathrm{MHz}, \mathrm{CDCl}_{3}\right): \delta_{\mathrm{H}}=7.77-8.28(\mathrm{~m}, 4 \mathrm{H}), 7.17-7.35(\mathrm{~m}, 4 \mathrm{H}), 6.4(\mathrm{~s}, 1 \mathrm{H}), 3.3\left(\mathrm{~d}, 2 \mathrm{H}, \mathrm{CH}_{2}\right), 2.29-2.32(\mathrm{~m}, 5 \mathrm{H})$, $1.21\left(\mathrm{~s}, 6 \mathrm{H}, 2 \mathrm{CH}_{3}\right)$.

13-(4-Methoxyphenyl)-3,3-dimethyl-3,4-dihydro-1 $H$-indazolo[2,1-b]phthalazine-1,6,11-(2H, 13H)-trione (2g): mp 219-221 ${ }^{\circ} \mathrm{C}$; FT-IR $\left(\mathrm{KBr}, \mathrm{cm}^{-1}\right)$ : The characteristic IR peaks: $3100,3000,2956,1664 ;{ }^{1} \mathrm{H} \mathrm{NMR}(90 \mathrm{MHz}$, $\left.\mathrm{CDCl}_{3}\right): \delta_{\mathrm{H}}=7.92-8.24(\mathrm{~m}, 4 \mathrm{H}), 7.54-7.82(\mathrm{~m}, 4 \mathrm{H}), 6.5(\mathrm{~s}, 1 \mathrm{H}), 3.77\left(\mathrm{~s}, \mathrm{OCH}_{3}\right) 3.33\left(\mathrm{~d}, 2 \mathrm{H}, \mathrm{CH}_{2}\right), 2.33(\mathrm{~s}$, $\left.2 \mathrm{H}, \mathrm{CH}_{2}\right), 1.2\left(\mathrm{~s}, 6 \mathrm{H}, 2 \mathrm{CH}_{3}\right)$.

3,4-Dihydro-3,3-dimethyl-13-(2-eylnaphtalene)-2H-indazolo[2,1-b]phthalazine-1,6,11(13H)-trione (2h): mp 249-251 ${ }^{\circ} \mathrm{C}$; FT-IR $\left(\mathrm{KBr}, \mathrm{cm}^{-1}\right)$ : The characteristic IR peaks: 3100, 3000, 2967, 1681, 1664; ${ }^{1} \mathrm{H}$ NMR (90 $\left.\mathrm{MHz}, \mathrm{CDCl}_{3}\right): \delta_{\mathrm{H}}=7.45-8.38(\mathrm{~m}, 11 \mathrm{H}), 6.62(\mathrm{~s}, 1 \mathrm{H}), 3.24-3.5(\mathrm{dd}, 2 \mathrm{H}), 2.33(\mathrm{~s}, 2 \mathrm{H}), 1.22(\mathrm{~s}, 6 \mathrm{H}) .{ }^{13} \mathrm{C} \mathrm{NMR}$ 
$\left(75 \mathrm{MHz}, \mathrm{CDCl}_{3}\right): 118.6,124,126.2,126.3,126.8,127.7,128,128.2,128.7,129,133.2,133.4,133.5,133.6$, $134.5,150.8,156,192$.

13-Ethyl-3,3-dimethyl-3,4-dihydro-1 $H$-indazolo[2,1-b]phthalazine-1,6,11(2H,13H)-trione (2i): mp 264$267^{\circ} \mathrm{C}$; FT-IR $\left(\mathrm{KBr}, \mathrm{cm}^{-1}\right)$ : The characteristic IR peaks: 3100, 3000, 2962, 2931, 1652; ${ }^{1} \mathrm{H}$ NMR $(90 \mathrm{MHz}$, $\left.\mathrm{CDCl}_{3}\right): \delta_{\mathrm{H}}=7.81-8.35(\mathrm{~m}, 4 \mathrm{H}), 5.69(\mathrm{~m}, 1 \mathrm{H}), 3.16\left(\mathrm{~d}, 2 \mathrm{H}, \mathrm{CH}_{2}\right), 2.16-2.37\left(\mathrm{~m}, 4 \mathrm{H}, 2 \mathrm{CH}_{2}\right), 1.19(\mathrm{~s}, 6 \mathrm{H}$, $\left.2 \mathrm{CH}_{3}\right), 0.65-0.82\left(\mathrm{t}, 3 \mathrm{H}, \mathrm{CH}_{3}\right)$.

3,4-Dihydro-3,3-dimethyl-13-(4-thiomethylphenyl)-2H-indazolo[2,1-b]phthalazine-1,6,11(13H)-trione (2j): $\mathrm{mp} 228-230^{\circ} \mathrm{C}$; FT-IR $\left(\mathrm{KBr}^{\mathrm{cm}} \mathrm{cm}^{-1}\right)$ : The characteristic IR peaks: 3100, 3000, 2959, 2978, 1663; ${ }^{1} \mathrm{H}$ NMR $(90$ $\left.\mathrm{MHz}, \mathrm{CDCl}_{3}\right): \delta_{\mathrm{H}}=7.84-8.37(\mathrm{~m}, 4 \mathrm{H}), 7.1-7.35(\mathrm{~m}, 4 \mathrm{H}), 6.4(\mathrm{~s}, 1 \mathrm{H}), 3.21-3.45\left(\mathrm{~d}, 2 \mathrm{H}, \mathrm{CH}_{2}\right), 2.42(\mathrm{~s}, 3 \mathrm{H})$, $2.34(\mathrm{~s}, 2 \mathrm{H}), 1.2(\mathrm{~s}, 6 \mathrm{H})$.

\subsection{The plausible mechanism}

A persuasive mechanism for the synthesis of diverse phthalazine-triones is illustrated as below. The reaction is followed by mixture of regents in $\mathrm{EtOH}$ at reflux conditions in the presence of the $\mathrm{Mn}$ supported nano-catalyst (Scheme 3).

The suggested mechanism is presumably in accordance of the Lewis acidity of the Mn supported nanocatalyst by connecting to the carbonyl group to simplify the nucleophilic attack of the enolic form of dimedone (Knoevenagel condensation) to aldehyde to form the intermediate with the subsequent deletion of water, the nucleophilic attack of phthalhydrazide, deletion of water, and the final cyclization to get the product.

\subsection{Comparison of Catalytic activity}

Table 3 shows the comparison of the previous procedures (entries 1-9) used for the synthesis of 3,4Dihydro-3,3-dimethyl-13-(4-methylphenyl)-2H-indazolo[2,1-b]phthalazine-1,6,11(13H)-trionewith our used method (entry 10). In general, each procedure includes some advantages that by focusing on the pervious routes we could declare this method could accelerate the process of reaction and be useful and efficient as well. 
Table 3

Comparison of the Mn supported nano-catalyst capability with the other catalysts in synthesis of 3,4dihydro-3,3-mimethyl-13-(4-methylphenyl)-2H-indazolo[2,1- $b]$ phthalazine-1,6,11(13H)-trione

\begin{tabular}{|c|c|c|c|c|c|c|}
\hline Entry & Catalyst & Solvent ${ }^{\mathrm{a}}$ & $\begin{array}{l}\mathrm{T}^{\mathrm{b}} \\
\left({ }^{\circ} \mathrm{C}\right)\end{array}$ & $\begin{array}{l}\text { Time } \\
(\min )\end{array}$ & $\begin{array}{l}\text { Yield } \\
\text { (\%) }\end{array}$ & Ref. \\
\hline 1 & MNPs-guanidine $(0.03 \mathrm{~g})$ & SF & 70 & 40 & 90 & 34 \\
\hline 2 & $\beta$-Cyclodextrin & $\mathrm{H}_{2} \mathrm{O}$ & 80 & 30 & 86 & 35 \\
\hline 3 & {$\left[\mathrm{Simp}_{3} \mathrm{PW}_{12} \mathrm{O}_{40}(0.03 \mathrm{~g})\right.$} & SF & 100 & 60 & 66 & 36 \\
\hline 4 & PTA@Fe ${ }_{3} \mathrm{O}_{4} / \mathrm{EN}-\mathrm{MIL}-101$ (0.02 g) & SF & 100 & 60 & 70 & 37 \\
\hline 5 & $\mathrm{Fe}_{3} \mathrm{O}_{4} @$ Silica sulfuric acid $(0.075 \mathrm{~g})$ & SF & 100 & 40 & 86 & 38 \\
\hline 6 & MNPs-PSA (0.03) & SF & 100 & 30 & 90 & 39 \\
\hline 7 & $\mathrm{H}_{2} \mathrm{SO}_{4}(0.015 \%$ mmole $)$ in $\mathrm{EtOH} / \mathrm{H}_{2} \mathrm{O}$ & EtOH & Reflux & 30 & 86 & 40 \\
\hline 8 & $\mathrm{MnFe}_{2} \mathrm{O}_{4} @ \mathrm{SiO}_{2} @ \mathrm{NH}-\mathrm{NH}_{2}-\mathrm{PTA}(0.03 \mathrm{~g})$ & SF & 80 & 30 & 87 & 41 \\
\hline 9 & CAN (5 \%mol) & PEG & 50 & 150 & 94 & 42 \\
\hline 10 & $\begin{array}{l}\mathrm{Fe}_{3} \mathrm{O}_{4} @ \mathrm{SiO}_{2} @ \mathrm{CPTMS} @ M B O L @ M n \\
(0.02 \mathrm{~g})\end{array}$ & EtOH & Reflux & 15 & 90 & PW \\
\hline
\end{tabular}

\subsection{Reusability of the Mn supported nano-catalyst}

To investigate the recyclability of the Mn supported nano-catalyst for environmental and commercial applications, it was tested with the model reaction, and found that it is relatively capable even after five runs and its activity was almost similar to the fresh one $(90,90,88,87$, and $84 \%)$ respectively (Fig. 8). The stability of the Mn supported nano-catalyst even after the 5th run was inspected by FT-IR and SEM techniques (Fig. 9-10).

\subsection{Antibacterial properties}

The antibacterial properties of the Mn supported nano-catalyst were studied against a number of grampositive and gram-negative bacterial strains, and DMSO was used as a blank (Table 4). The catalyst inhibited the growth of bacterial strains, producing a zone of inhibition of diameter 5-30 mm. The Mn supported nano-catalyst was even more effective against Serratia marcescens in gram-negative bacteria than the standard tetracycline antibiotic. Since the comparison of the size of inhibition zones is generally not reliable, the MIC value of the compound was also determined. The results indicated that the MIC value of the Mn supported nano-catalyst against the tested organisms was about $8 \mathrm{mg} / \mathrm{mL}$. The MIC value of standard tetracycline antibiotic is about $8 \mathrm{mg} / \mathrm{mL}$. 
Table 4 Antibacterial activity of Mn supported nano catalyst that was expressed as diameter of inhabitation zone $(\mathrm{mm})$ and minimum inhibitory concentration (MIC)

\begin{tabular}{|c|c|c|c|}
\hline Microorganisms & Standard & Blank & $\begin{array}{l}\text { Zone of inhabitation } \\
(\mathrm{mm})\end{array}$ \\
\hline MIC (mg/mL) & $\begin{array}{l}\text { Tetracycline (10 } \\
\mathrm{mg} / \mathrm{mL}) \\
8\end{array}$ & $\begin{array}{l}\text { DMSO } \\
-\end{array}$ & $\begin{array}{l}\text { the Mn catalyst } \\
8\end{array}$ \\
\hline Gram (+) & 30 & - & 10 \\
\hline Bacillus thuringiensis & 36 & - & 20 \\
\hline \multicolumn{4}{|l|}{ Staphylococcus aureus } \\
\hline Gram (-) & 25 & - & 20 \\
\hline \multirow{2}{*}{$\begin{array}{l}\text { Pseudomonas aeruginosa Serratia } \\
\text { marcescens }\end{array}$} & 20 & - & 30 \\
\hline & 22 & - & 15 \\
\hline $\begin{array}{l}\text { Escherichia coli } \\
\text { Klebsiella pneumoniae }\end{array}$ & 25 & - & 5 \\
\hline
\end{tabular}

\section{Conclusion}

In conclusion, we were successful to synthesize a novel Mn nano-catalyst supported on magnetic iron oxide functionalized with mercaptobenzoxazole as an appropriate surface for synthesis of $2 \mathrm{H}$ Indazolo[1,2-b]phthalazine-triones from the one pot three-component condensation reaction of aldehydes, dimedone and phthalhydrazide in refluxed ethanol in fine yields and short reaction times. In fact iron oxide nanoparticles through the noticeable properties such as small size, high magne-tism and low toxicity would be a proper methods for chemistry synthesis. Also we inspected the antibacterial properties of Mn nano catalyst against a number of gram-positive and gram-negative bacterial strains and determined the nano catalyst would be more effective against Serratia marcescens in gram-negative bacteria than the standard tetracycline antibiotic. Environmental issues revealed that the $\mathrm{Mn}$ nano catalyst would be used for five runs without significant loss of the catalytic activity.

\section{Declarations}

\section{Acknowledgement}

Gratefully this project was financially supported by Bu-Ali Sina University.

\section{References}


1. F. Al-Assar, K.N. Zelenin, E.E. Lesiovskaya, I.P. Bezhan, B.A. Chakchir, Pharm. Chem. J.2002, 36, 598. https://doi.org/10.1023/A:1022665331722.

2. C.K. Ryu, R.E. Park, M.Y. Ma, J.H. Nho, Bioorg. Med. Chem. Lett. 2007, 17, 2577. https://doi.org/10.1016/j.bmcl.2007.02.003.

3. J. Sinkkonen, V.Ovcharenko, K.N. Zelenin, I.P. Bezhan, B.A. Chakchir, F. Al-Assar, K.Pihlaja, Eur. J. Org. Chem. 2002, 13, 2046. https://doi.org/10.1002/1099-0690(200207)2002:13<2046::AIDEJOC2046>3.0.CO;2-C.

4. Zhang, L.P. Guan, X.Y. Sun, C.X. Wei , K.Y. Chai, Z.S. Quan, Chem. Biol Drug.Des. 2009, $73,313$. https://doi.org/10.1111/j.1747-0285.2009.00776.x.

5. Li, Y.F. Zhao, X.Y. Yuan, J.X. Xu, P. Gong, Molecules. 2006, 11, 574. https://doi.org/10.3390/11070574

6. Nomoto , H. Obase, H. Takai, M. Teranishi, J. Nakamura, K. Kubo, Chem. Pharm. Bull. 1990, $38,2179$. https://doi.org/10.1248/cpb.38.2179.

7. Xu, and Q.X. Guo, Heterocycles2004, 63, 903-974.

8. V. Karunaratne, R.G. Sarkisian, J. Reeves, Y. Deng, K.A. Wheeler, and H. Wang, “Multicomponent Reaction through Cooperative Tr,io Catalysis Incorporating Enamine, BrønstedAcid and Metal Lewis Acid Catalysis: A Concise Route to Access Chromans," Organic \& Biomolecular Chemistry 15, no. 23 (2017): 4933-36. https://doi.org/10.1039/C70B00753A.

9. Kumar, and R.A. Maurya, "Synthesis of polyhydroquinoline derivatives through unsymmetric Hantzsch reaction using organocatalysts," Tetrahedron63, no. 9 (2007): 1946-1952. https://doi.org/10.1016/j.tet.2006.12.074.

10. V. Bhaskaruni, S. Maddila, K.K. Gangu, and S.B. Jonnalagadda, "A Review on multi-component green synthesis of $\mathrm{N}$-containing heterocycles using mixed oxides as heterogeneous catalysts," Arabian Journal of Chemistry13, no. 1 (2020): 1142-1178. https://doi.org/10.1016/j.arabjc.2017.09.016.

11. N. Chen, L.P. Mo, Z.S. Cui, and Z.H. Zhang, "Magnetic nanocatalysts: synthesis and application in multicomponent reactions." Current Opinion in Green and Sustainable Chemistry15 (2019): 27-37. https://doi.org/10.1016/j.cogsc.2018.08.009.

12. Sayyafi, M. Seyyedhamzeh, H.R. Khavasi, and A. Bazgir, "One-pot, three-component route to $2 \mathrm{H}$ indazolo [2, 1-b] phthalazine-triones," Tetrahedron64, no. 10 (2008): 2375-2378. https://doi.org/10.1016/j.tet.2008.01.006.

13. Shekouhy, and A. Hasaninejad, "Ultrasound-promoted catalyst-free one-pot four component synthesis of $2 \mathrm{H}$-indazolo [2, 1-b] phthalazine-triones in neutral ionic liquid 1-butyl-3methylimidazolium bromide," Ultrasonics sonochemistry19, no. 2 (2012): 307-313. https://doi.org/10.1016/j.ultsonch.2011.07.011.

14. Abbasi, S.M.R. Nazifi, Z.S. Nazifi, and A.R. Massah, "Synthesis, characterization and in vitro antibacterial activity of novel phthalazine sulfonamide derivatives," Journal of Chemical Sciences129, no. 8 (2017): 1257-1266. https://doi.org/10.1007/s12039-017-1337-8.

15. Kiasat, A. Mouradezadegun, and J. Saghanezhad, "Phospho sulfonic acid: A novel and efficient solid acid catalyst for the one-pot preparation of $2 \mathrm{H}$-indazolo [2, 1-b]-phthalazine-triones," Journal of the 
Serbian Chemical Society78, no. 4 (2013): 469-476. https://doi.org/10.2298/JSC120508088K.

16. Albadi, M. Jalali, and A. Momeni, "Cobalt-based nanocatalyst catalyzed one-pot four-component synthesis $2 \mathrm{H}$-indazolo [2, 1-b] phthalazine-triones under solvent-free condition," Research on Chemical Intermediates44, no. 4 (2018): 2395-2404.S. https://doi.org/10.1007/s11164-017-3236-5.

17. Nikzad Shalkouhi, H. Kefayati, and S. Shariati, "Synthesis, characterization and catalytic application of $\mathrm{Fe}_{3} \mathrm{O}_{4} @ \mathrm{Cys}-\mathrm{SO}_{3} \mathrm{H}$ for preparation of $2 \mathrm{H}$-indazolo [1, 2-b] phthalazine-triones," Iranian Journal of Catalysis 8, no. 3 (2018): 213-220.

18. Mousapour, F. Shirini, and M. Abedini, "Efficient Synthesis of $2 \mathrm{H}-$ Indazolo [2, 1-b] Phthalazine-Triones Using [PVPH] $\mathrm{ClO}_{4}$ as a Modified Polymeric Catalyst," Polycyclic Aromatic Compounds(2019): 1-8 https://doi.org/10.1080/10406638.2019.1593863.

19. Sabitha, C. Srinivas, A. Raghavendar, and J.S. Yadav, "Phosphomolybdic Acid (PMA)-SiO2 as a Heterogeneous Solid Acid Catalyst for the One-Pot Synthesis of 2H-Indazolo [1, 2-b] phthalazinetriones," Helvetica Chimica Acta93, no. 7 (2010): 1375-1380. https://doi.org/10.1002/hlca.200900378.

20. Doustkhah, and S. Rostamnia, "Covalently bonded sulfonic acid magnetic graphene oxide: Fe304@ GO-Pr-SO3H as a powerful hybrid catalyst for synthesis of indazolophthalazinetriones," Journal of colloid and interface science478 (2016): 280-287. https://doi.org/10.1016/j.jcis.2016.06.020.

21. Nagarapu, R. Bantu, and H.B. Mereyala, "TMSCl-mediated one-pot, three-component synthesis of $2 \mathrm{H}-$ indazolo [2, 1-b] phthalazine-triones," Journal of Heterocyclic Chemistry46, no. 4 (2009): 728-731. https://doi.org/10.1002/jhet.135.

22. Varghese, A. Nizam, R. Kulkarni, and L. Georg, "Solvent-free synthesis of 2H-indazolo [2, 1-b] phthalazine-triones promoted by cavitational phenomenon using iodine as catalyst," European Journal of Chemistry4, no. 2 (2013): 132-137. https://doi.org/10.5155/eurjchem.4.2.132-137.746.

23. Mosaddegh, and A. Hassankhani, "A rapid, one-pot, four-component route to $2 \mathrm{H}$-indazolo [2, 1-b] phthalazine-triones," Tetrahedron Letters52, no. 4 (2011): 488-490.

https://doi.org/10.1016/j.tetlet.2010.08.099.

24. Abedini, F. Shirini, and M. Mousapour, "Poly (vinylpyrrolidinium) perchlorate as a new and efficient catalyst for the promotion of the synthesis of polyhydroquinoline derivatives via Hantzsch condensation," Research on Chemical Intermediates42, no. 3 (2016): 2303-2315. https://doi.org/10.1007/s11164-015-2150-y.

25. Teimuri-Mofrad, S. Esmati, M. Rabiei, and M. Gholamhosseini-Nazari, "Efficient synthesis of new pyrano $[3,2-b]$ pyran derivatives via $\mathrm{Fe}_{3} \mathrm{O}_{4} @ \mathrm{SiO}_{2}-\mathrm{IL}-\mathrm{Fc}$ catalyzed three-component reaction," Heterocyclic Communications23, no. 6 (2017): 439-444. https://doi.org/10.1515/hc-20170140.

26. Kaur, J.T. Hupp, and S.T. Nguyen, "Porous organic polymers in catalysis: opportunities and challenges," ACS Catalysis1, no. 7 (2011): 819-835. https://doi.org/10.1021/cs200131g 
27. Zhang, and S.N. Riduan, "Functional porous organic polymers for heterogeneous catalysis," Chemical Society Reviews41, no. 6 (2012): 2083-2094. https://doi.org/10.1039/C1CS15227K.

28. Polshettiwar, R. Luque, A. Fihri, H. Zhu, and M.B. Basset, "Magnetically recoverable nanocatalysts," Chemical reviews111, no. 5 (2011): 3036-3075. https://doi.org/10.1021/cr100230z.

29. Nasrollahzadeh, Z. Issaabadi, and S.M. Sajadi, 2018. "Fe ${ }_{3} \mathrm{O}_{4} @ \mathrm{SiO}_{2}$ nanoparticle supported ionic liquid for green synthesis of antibacterially active 1-carbamoyl-1-phenylureas in water," RSC Advances8, no. 49 (2018): 27631-27644. 10.1039/C8RA04368J.

30. J. Malek, S.H. Chaki, J.P. Tailor, and M.P. Deshpande, "Nonisothermal decomposition kinetics of pure and $\mathrm{Mn}$-doped $\mathrm{Fe}_{3} \mathrm{O}_{4}$ nanoparticles," Journal of Thermal Analysis and Calorimetry 132, no. 2 (2018): 895-905. https://doi.org/10.1007/s10973-018-7013-5.

31. Jiang, K. Huang, D.Yang, S. Wang, H. Zhong, and C. Jiang, "Facile preparation of $\mathrm{Mn}_{3} \mathrm{O}_{4}$ hollow microspheres via reduction of pentachloropyridine and their performance in lithium-ion batteries," RSC advances 7, no. 14 (2017): 8264-8271. 10.1039/C6RA24803A.

32. Habibi, S. Heydari, M. Afsharfarnia, and Z. Rostami, "A versatile synthesis of arylaminotetrazoles by a magnetic Fe@Phendiol@ Mn nano-particle catalyst and its theoretical studies," Applied Organometallic Chemistry 31, no. 12 (2017): e3826. https://doi.org/10.1002/aoc.3826.

33. Atashkar, A. Rostami, H. Gholami, and B. Tahmasbi, "Magnetic nanoparticles $\mathrm{Fe}_{3} \mathrm{O}_{4}$-supported guanidine as an efficient nanocatalyst for the synthesis of $2 \mathrm{H}$-indazolo [2, 1-b] phthalazine-triones under solvent-free conditions," Research on Chemical Intermediates41, no. 6 (2015): 3675-3681. https://doi.org/10.1007/s11164-013-1480-x

34. V. Chate, P.K. Bhadke, M.A. Khande, J.N. Sangshetti, and C.H. Gill, "ß-cyclodextrin as a supramolecular catalyst for the synthesis of $2 \mathrm{H}$-indazolo $[2,1-\mathrm{b}]$ phthalazine-trione derivatives in water and their antimicrobial activities," Chinese Chemical Letters28, no. 7 (2017): 1577-1582. https://doi.org/10.1016/j.cclet.2017.03.007.

35. Tayebee, M.F. Abdizadeh, B. Maleki, and E. Shahri, "Heteropolyacid-based ionic liquid [Simp] ${ }_{3} \mathrm{PW}_{12} \mathrm{O}_{40}$ nanoparticle as a productive catalyst for the one-pot synthesis of $2 \mathrm{H}$-indazolo [2, 1-b] phthalazine-triones under solvent-free conditions," Journal of Molecular Liquids241 (2017): 447-455. https://doi.org/10.1016/j.molliq.2017.06.033.

36. Hashemzadeh, M.M. Amini, R. Tayebee, A. Sadeghian, L.J. Durndell, M.A. Isaacs, and A.F. Lee, "A magnetically-separable $\mathrm{H}_{3} \mathrm{PW}_{12} \mathrm{O}_{40} @ \mathrm{Fe}_{3} \mathrm{O}_{4}$ /EN-MIL-101 catalyst for the one-pot solventless synthesis of 2H-indazolo [2, 1-b] phthalazine-triones," Molecular Catalysis 440 (2017): 96-106. https://doi.org/10.1016/j.mcat.2017.07.010.

37. R. Kiasat, and J. Davarpanah, " $\mathrm{Fe}_{3} \mathrm{O}_{4} @$ silica sulfuric acid nanoparticles: an efficient reusable nanomagnetic catalyst as potent solid acid for one-pot solvent-free synthesis of indazolo [2, 1-b] phthalazine-triones and pyrazolo [1, 2-b] phthalazine-diones," Journal of Molecular Catalysis A: Chemica/373 (2013): 46-54. https://doi.org/10.1016/j.molcata.2013.03.003 
38. Rostami, B. Tahmasbi, and A. Yari,"Magnetic nanoparticle immobilized N-propylsulfamic acid as a recyclable and efficient nanocatalyst for the synthesis of $2 \mathrm{H}$-indazolo [2, 1-b] phthalazine-triones in solvent-free conditions: comparison with sulfamic acid," Bulletin of the Korean Chemical Society 34, no. 5 (2013): 1521-1524. https://doi.org/10.5012/bkcs.2013.34.5.1521.

39. M. Khurana, and D. Magoo, "Efficient one-pot syntheses of $2 \mathrm{H}$-indazolo $[2,1$-b] phthalazine-triones by catalytic $\mathrm{H}_{2} \mathrm{SO}_{4}$ in water-ethanol or ionic liquid," Tetrahedron Letters50, no. 52 (2009): 7300-7303. https://doi.org/10.1016/j.tetlet.2009.10.032.

40. Mozafari, and F. Heidarizadeh, "Phosphotungstic acid supported on SiO2@ NHPhNH2 functionalized nanoparticles of $\mathrm{MnFe} 2 \mathrm{O} 4$ as a recyclable catalyst for the preparation of tetrahydrobenzo [b] pyran and indazolo [2, 1-b] phthalazine-triones," Polyhedron 162 (2019): 263-276. https://doi.org/10.1016/j.poly.2019.01.065.

41. Mazaahir, C. Ritika, and J. Anwar "Efficient CAN catalyzed synthesis of $1 \mathrm{H}$-indazolo [1, 2-b] phthalazine-1, 6, 11-triones: An eco-friendly protocol," Chinese Science Bulletin57, no. 18 (2012): 2273-2279. https://doi.org/10.1007/s11434-012-5081-7.

42. Abedini, F. Shirin, and J. Mohammad-Alinejad Omran, "Efficient synthesis of 2H-indazolo [2, 1-b] phthalazine-trione derivatives using succinimidinium $\mathrm{N}$-sulfonic acid hydrogen sulfate as a new ionic liquid catalyst," Journal of Molecular Liquids212 (2015): 405-412.

https://doi.org/10.1016/j.molliq.2015.09.014.

\section{Tables}

Due to technical limitations, table 2 is only available as a download in the Supplemental Files section.

\section{Figures}

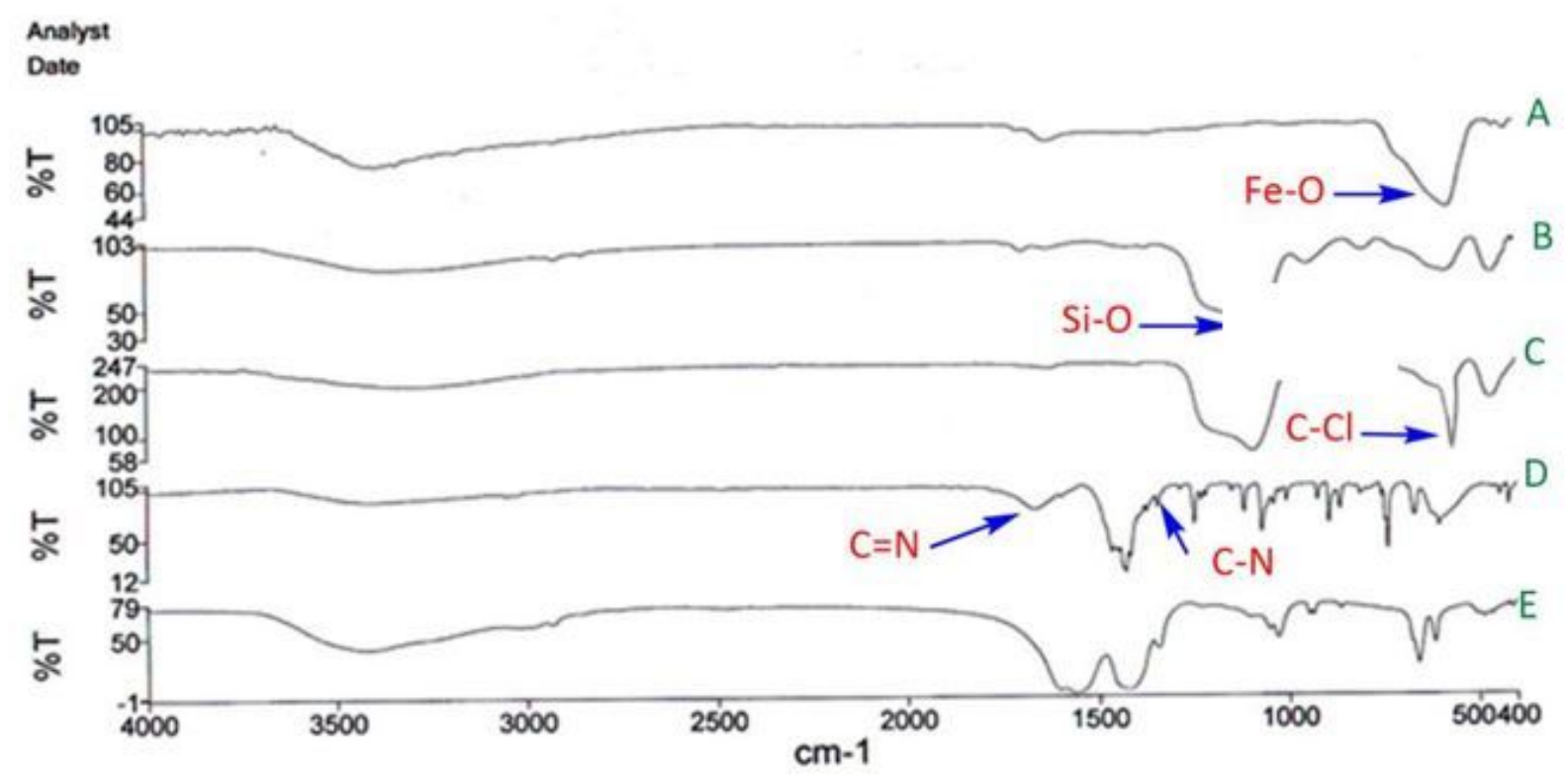


Figure 1

FT-IR spectra of five steps of preparation of nano-catalyst (A, B, C, D and E)

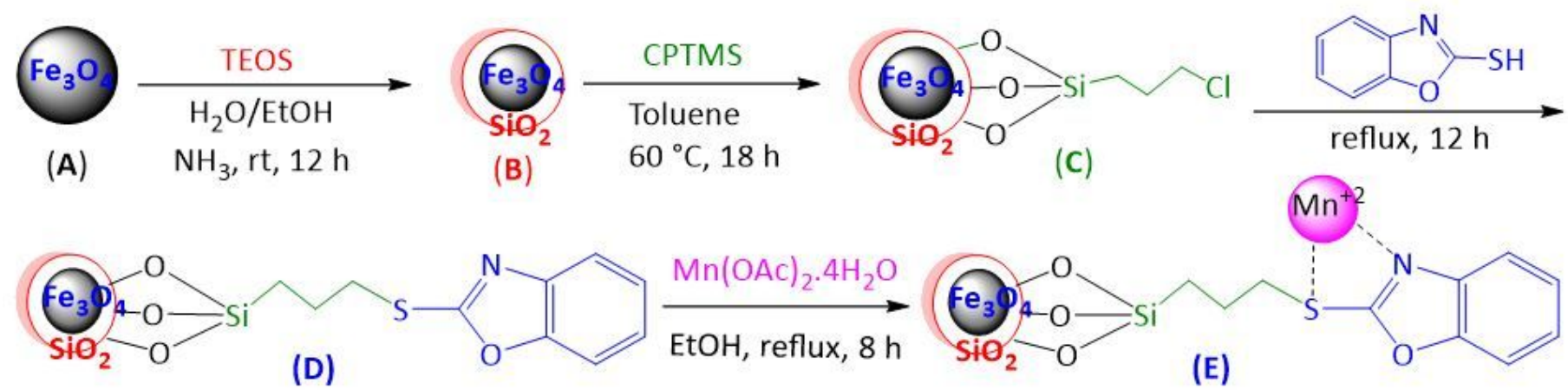

Figure 2

Synthesis of a novel Mn supported nano-catalyst 


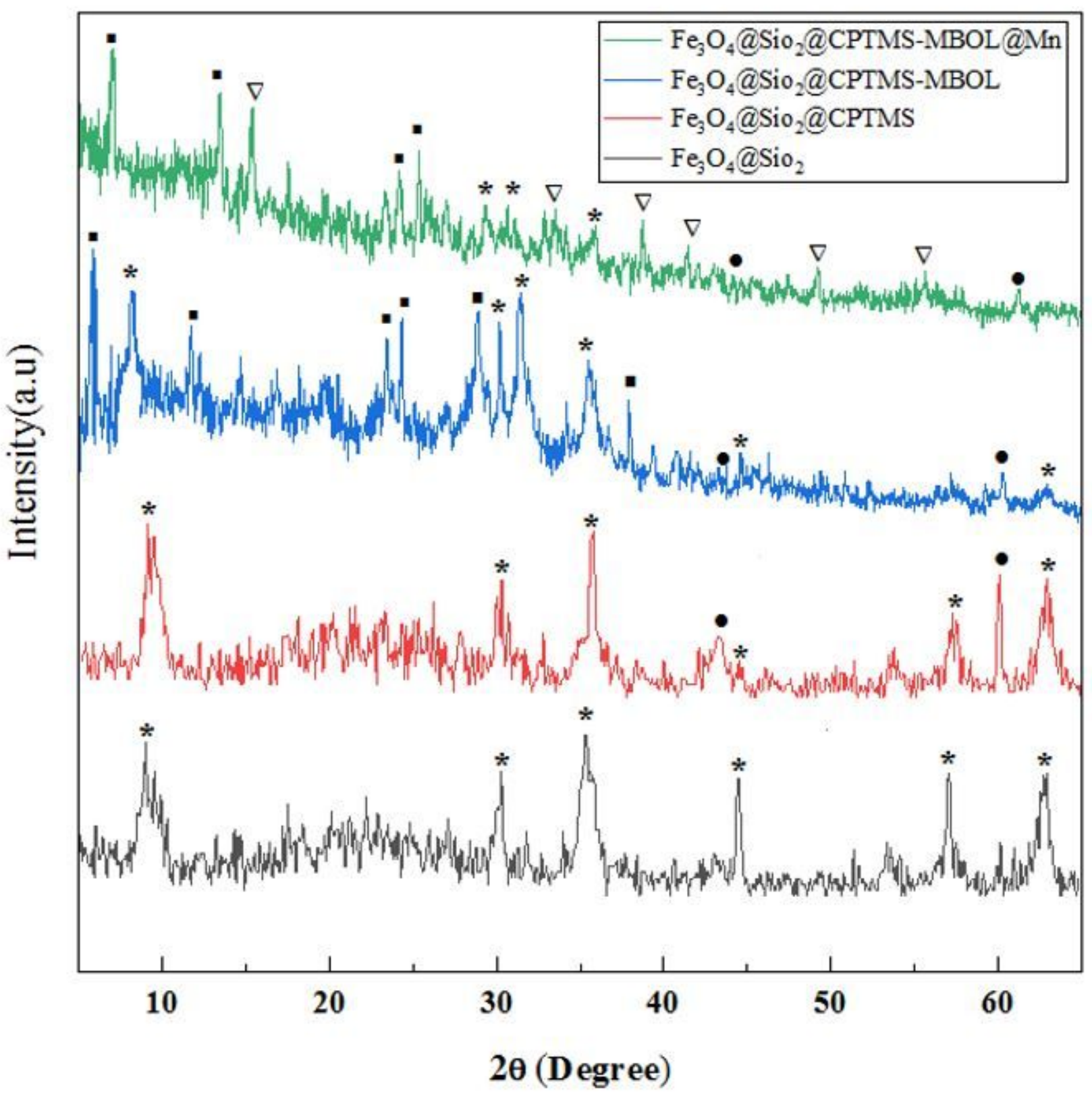

Figure 3

The XRD pattern of Fe304@SiO2@CPTMS@MBOL@Mn<smiles></smiles> 
Figure 4

Synthesis of diverse indazolophthalazinetriones

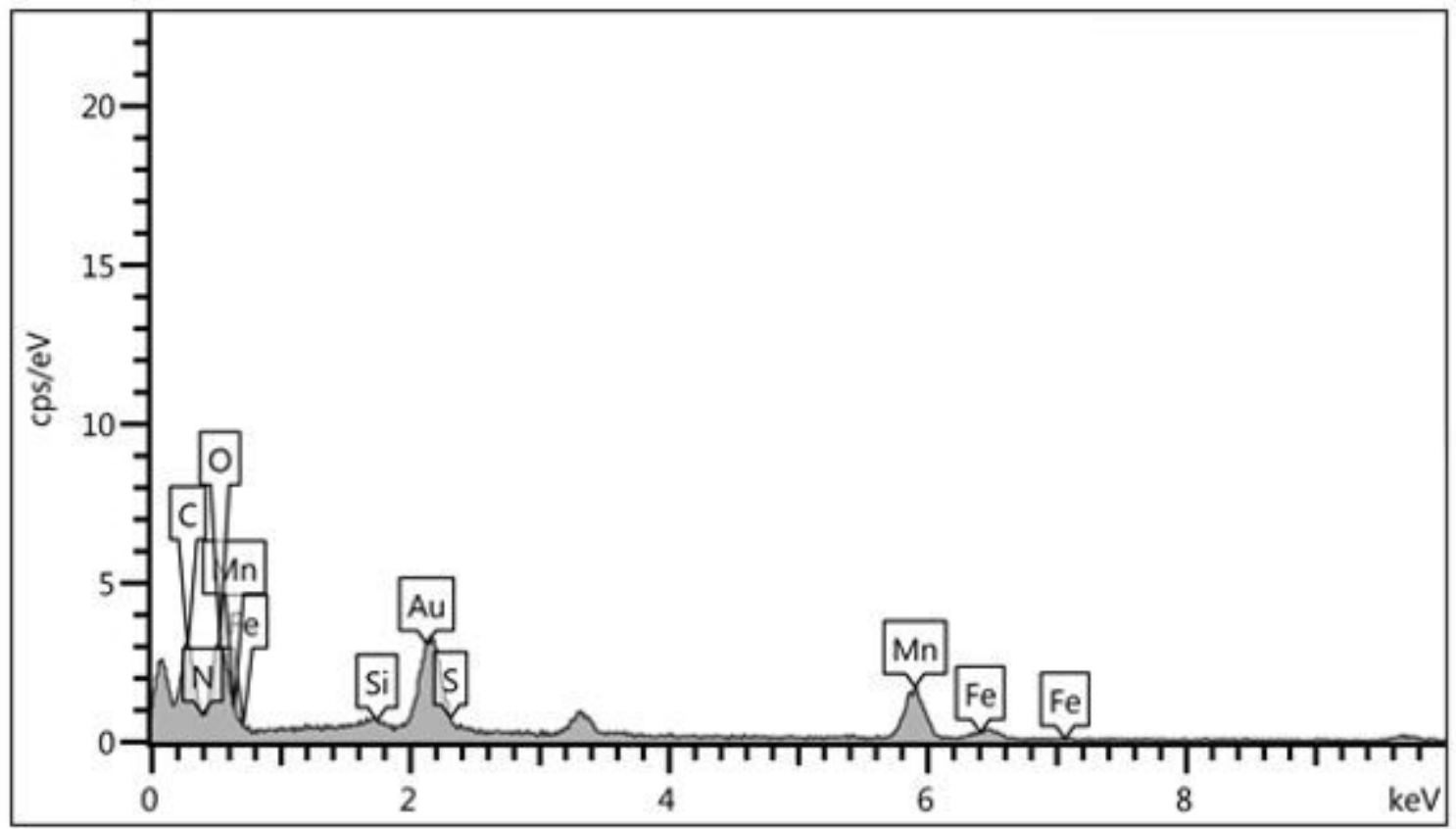

Figure 5

The EDX analysis of the Mn supported nano-catalyst

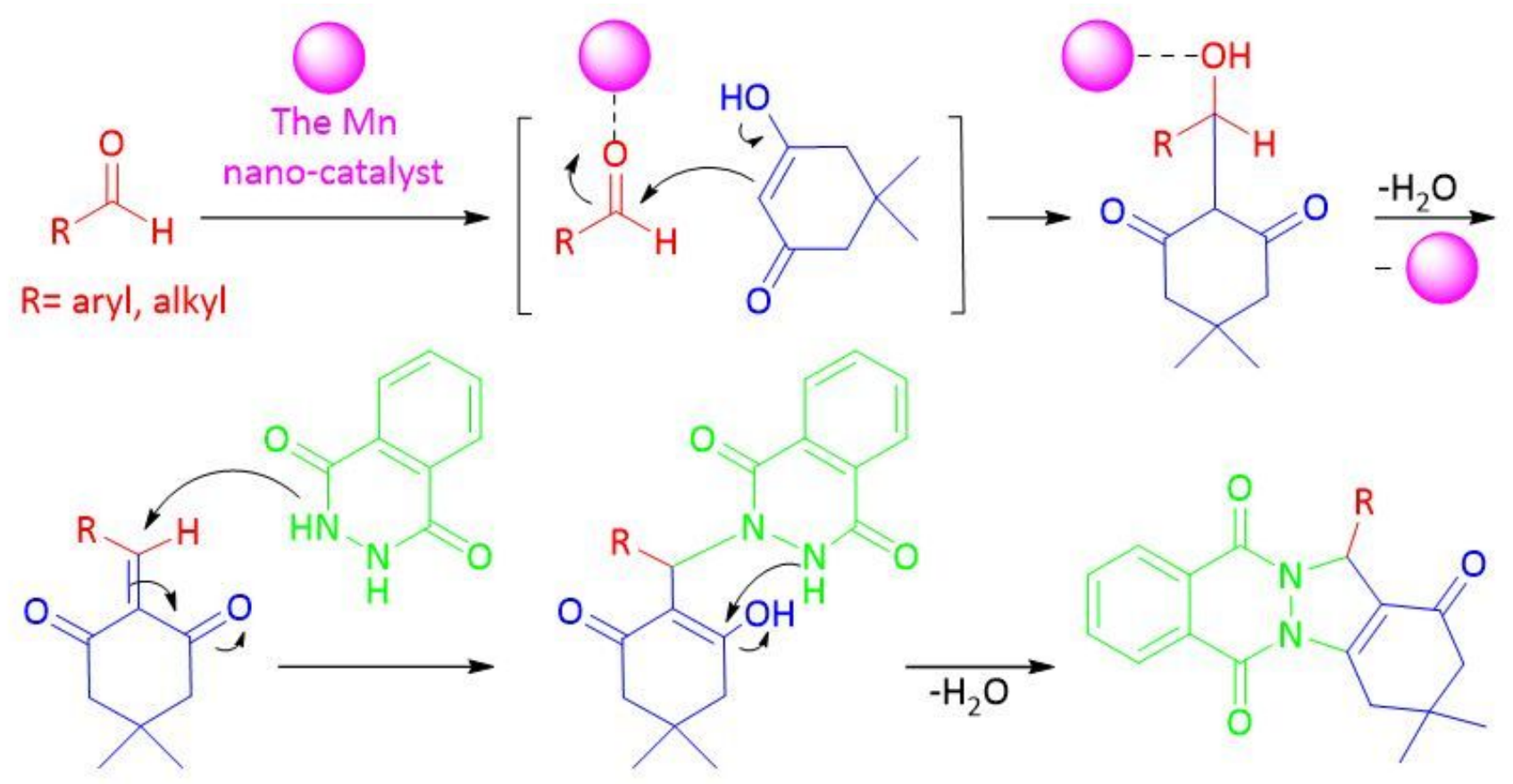

Figure 6 
Suggested mechanism for the synthesis of indazolophthalazinetrione
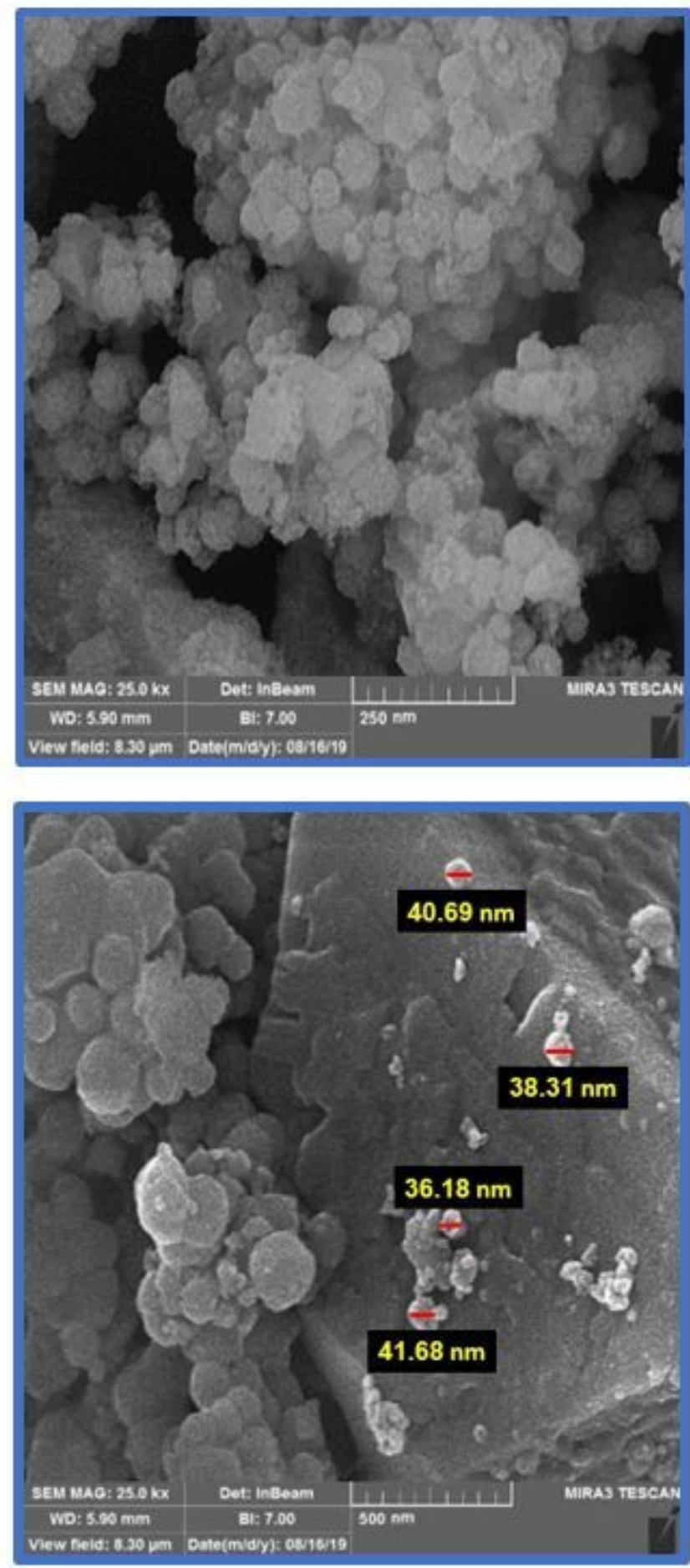
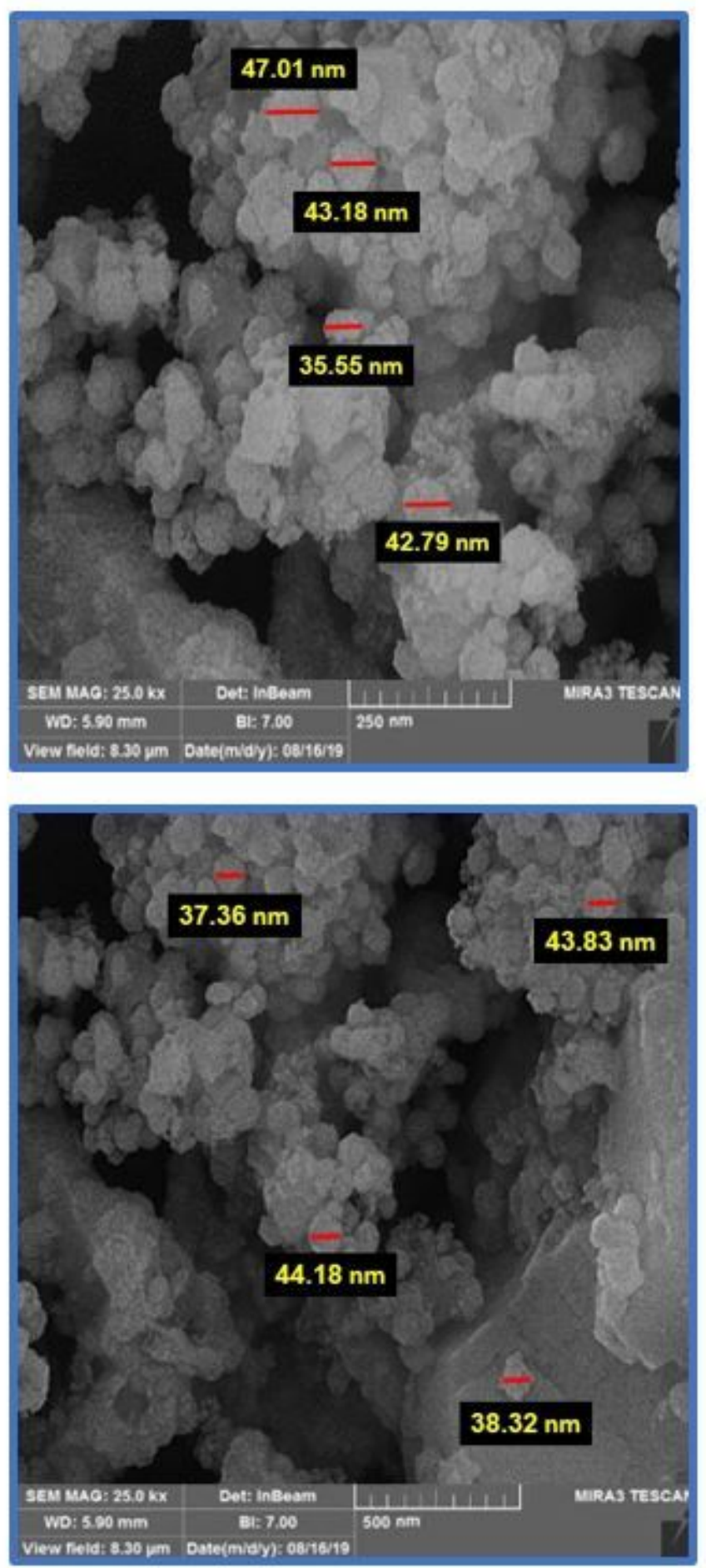

\section{Figure 7}

The SEM images of the Mn supported nano-catalyst 

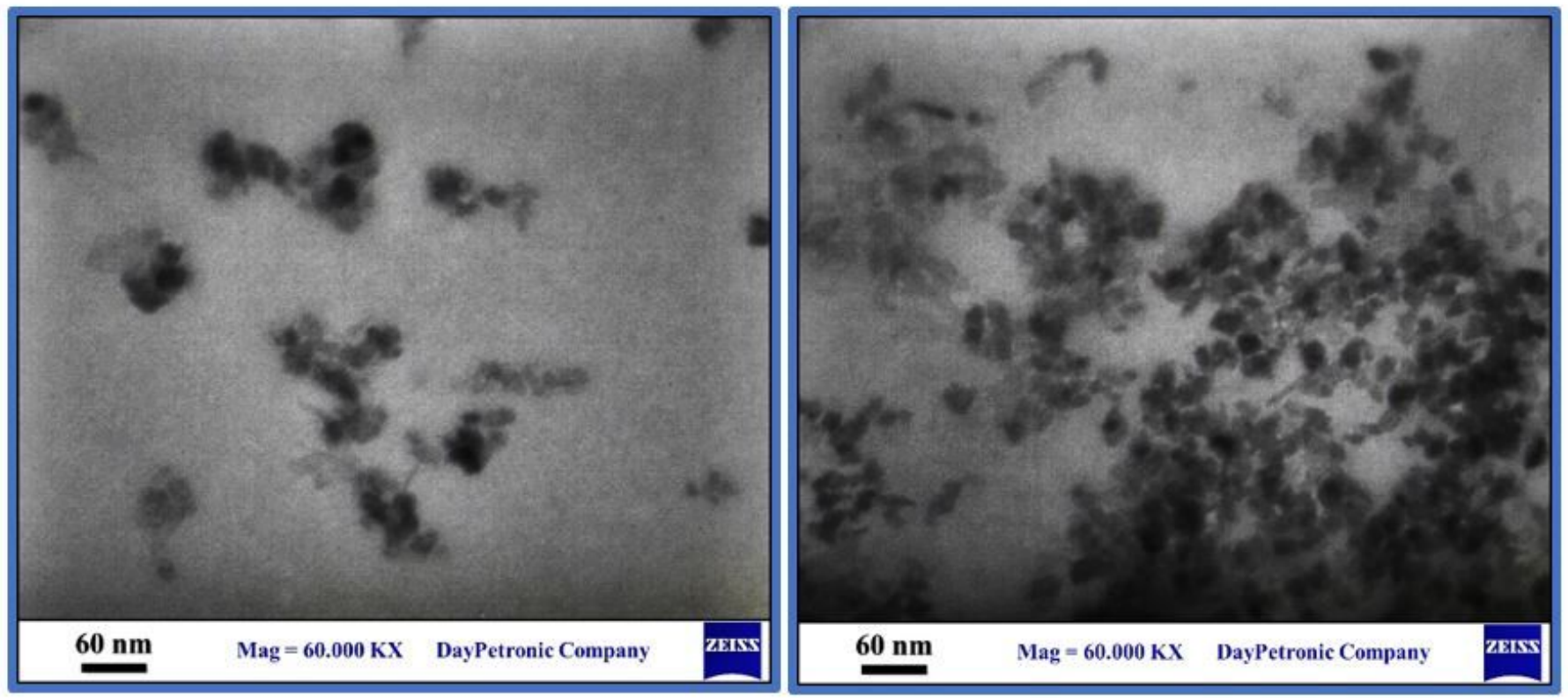

\section{Figure 8}

The TEM images of the Mn supported nano-catalyst
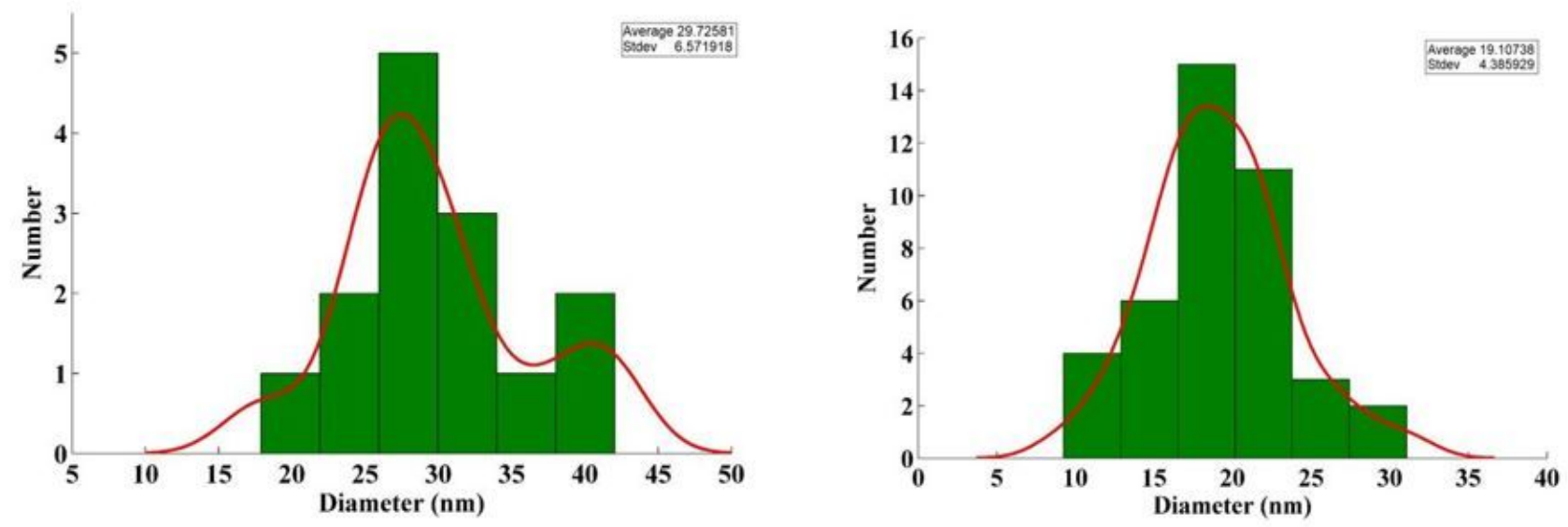

Figure 9

The particle size distribution of $\mathrm{Mn}$ - catalyst 


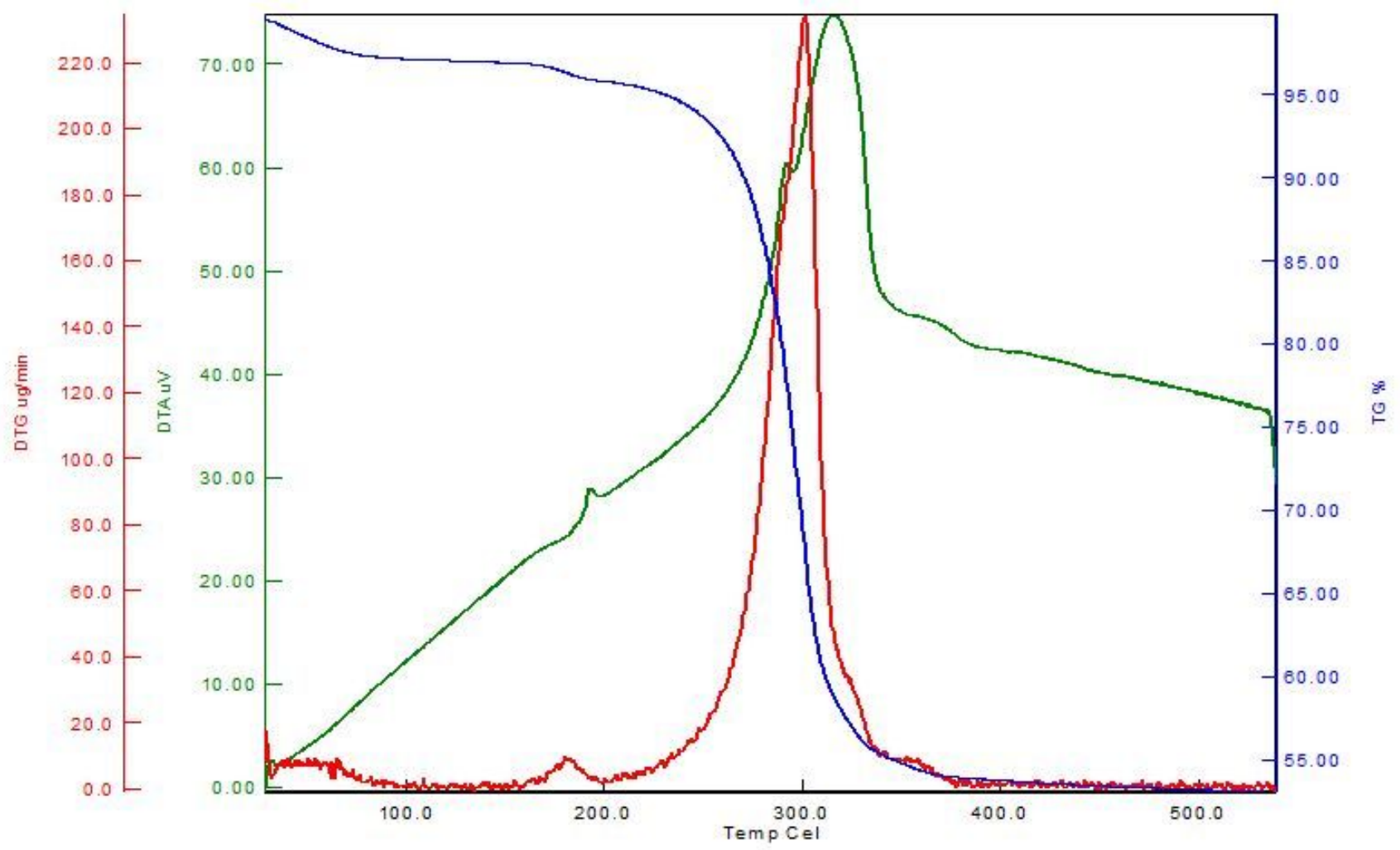

Figure 10

TGA-DTA patterns of the Mn supported nano-catalyst catalyst 

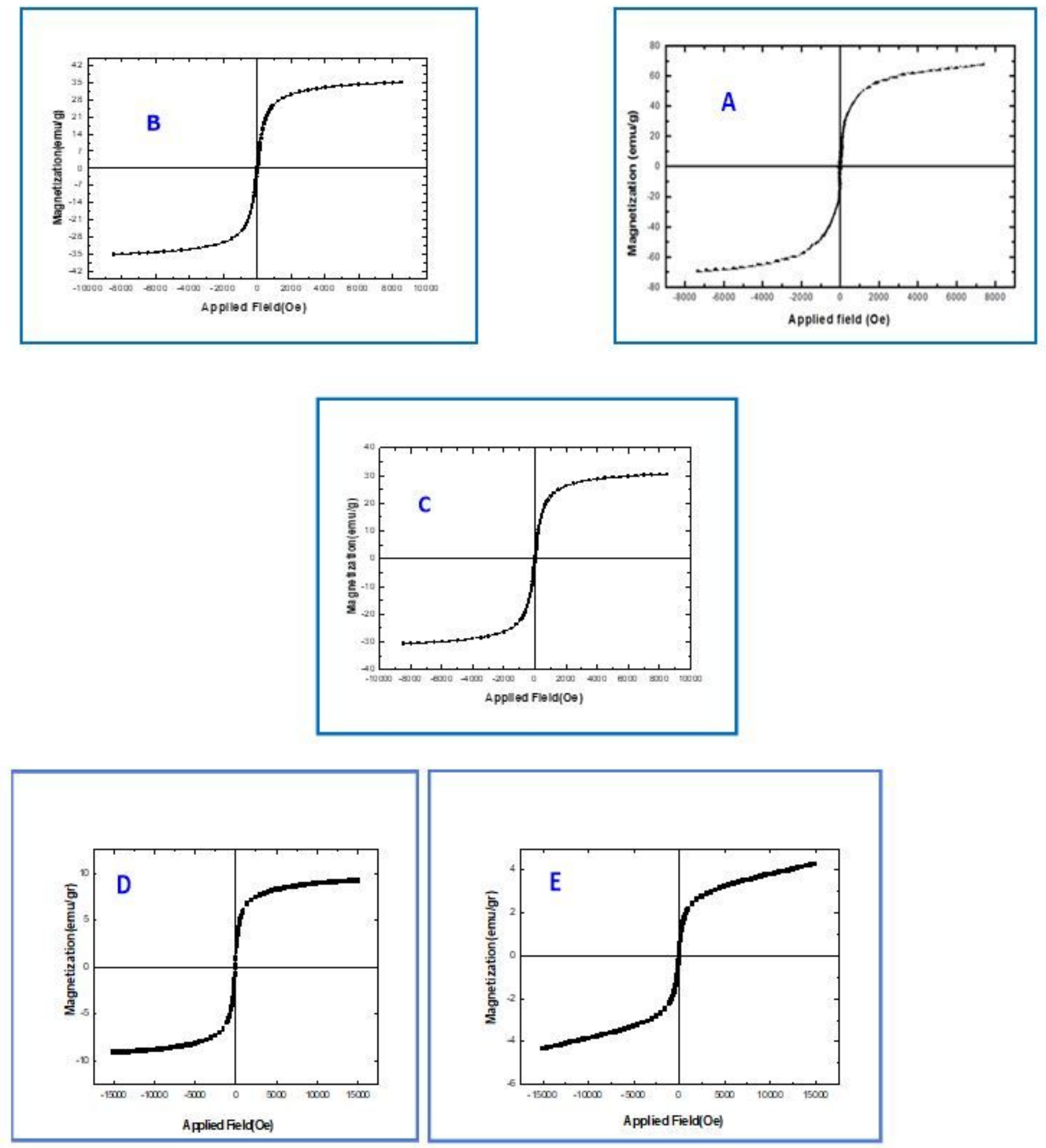

Figure 11

The VSM analysis of A, B, C, D and E 


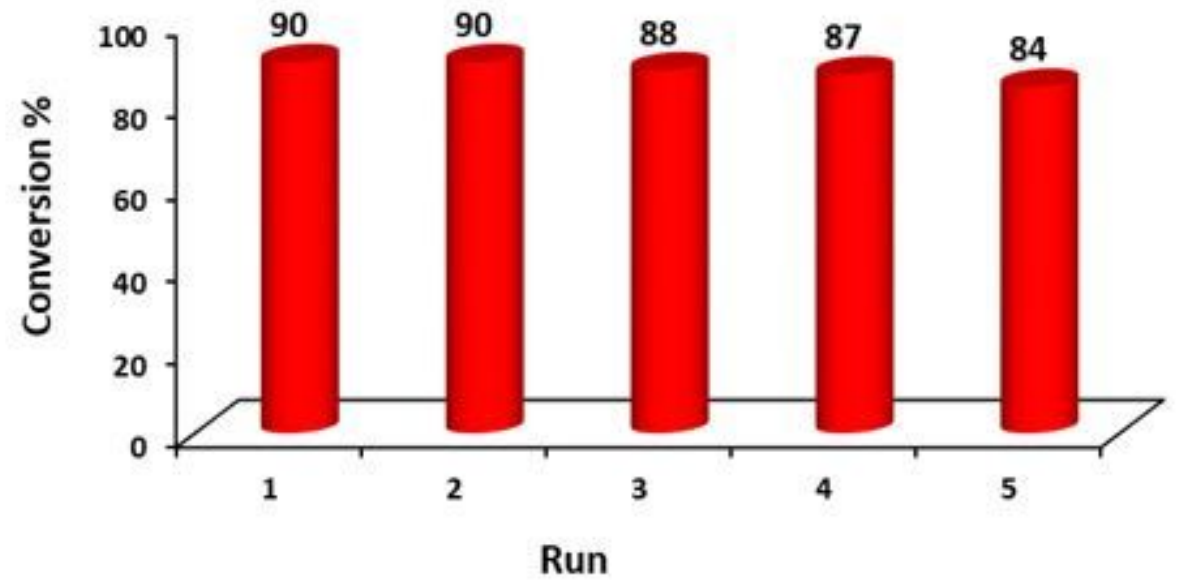

Figure 12

Reusability of the Mn supported nano-catalyst 


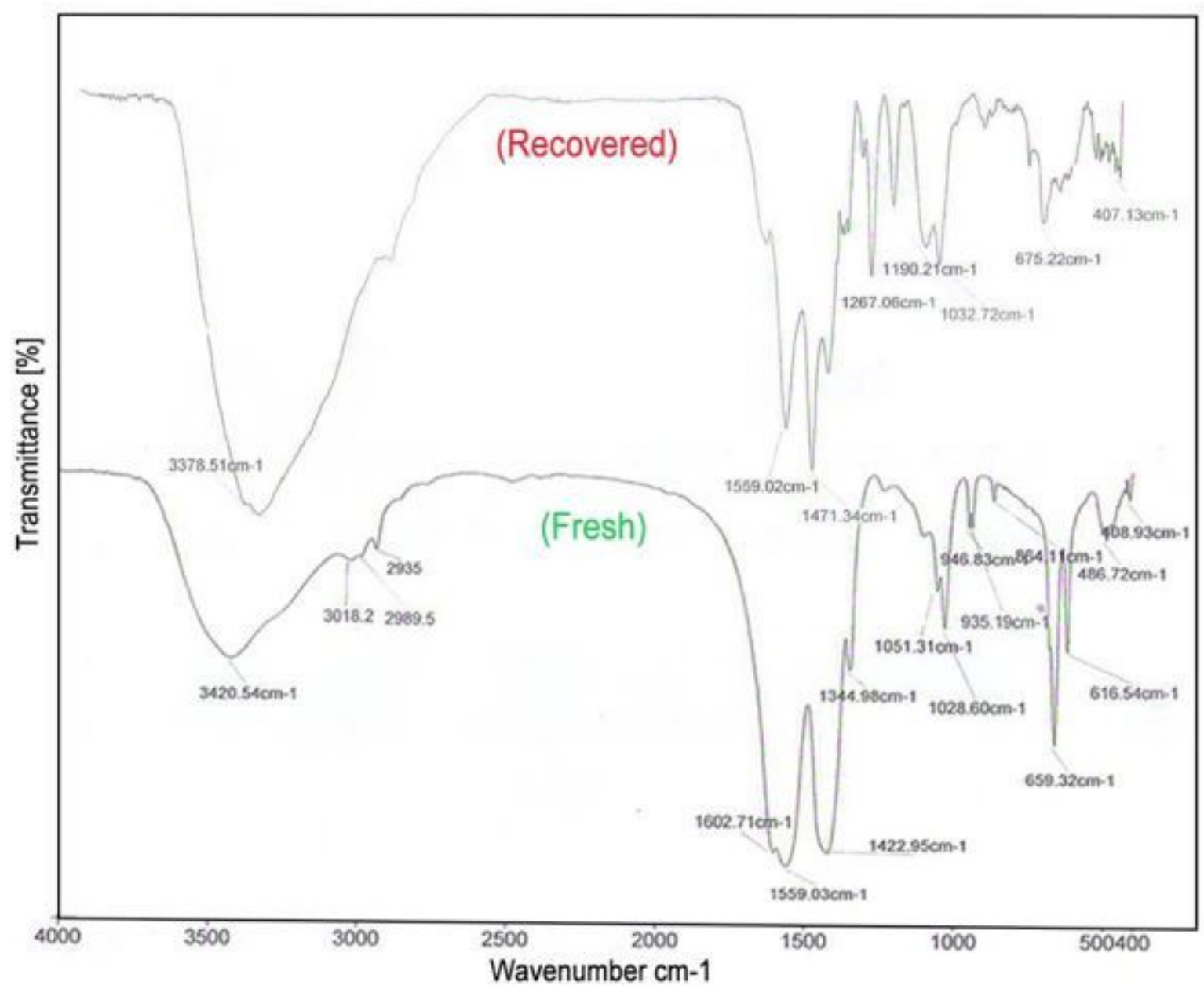

Figure 13

FT-IR spectra of fresh and recovered Mn supported nano-catalyst 

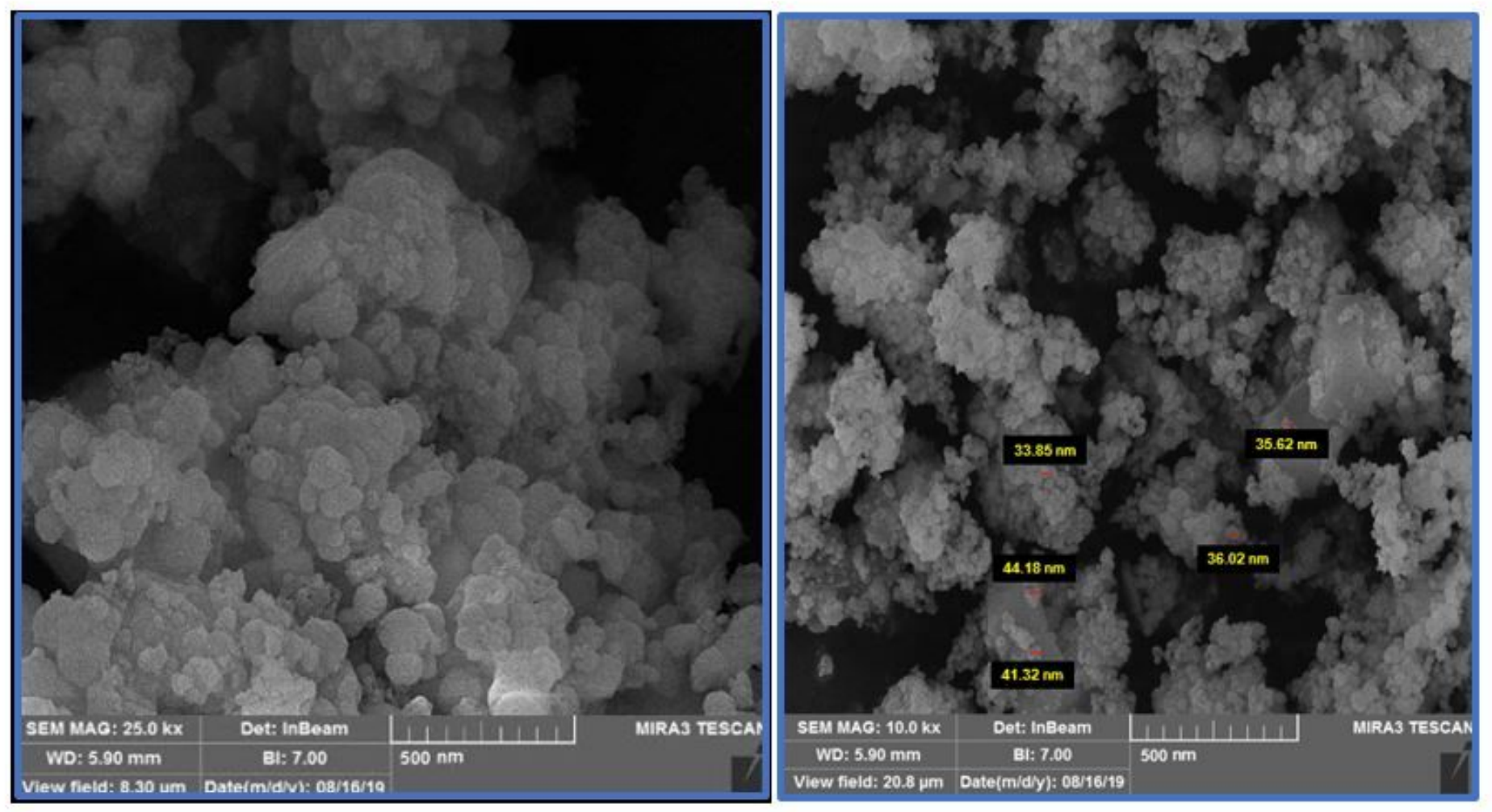

Figure 14

SEM image of recovered Mn supported nano-catalyst
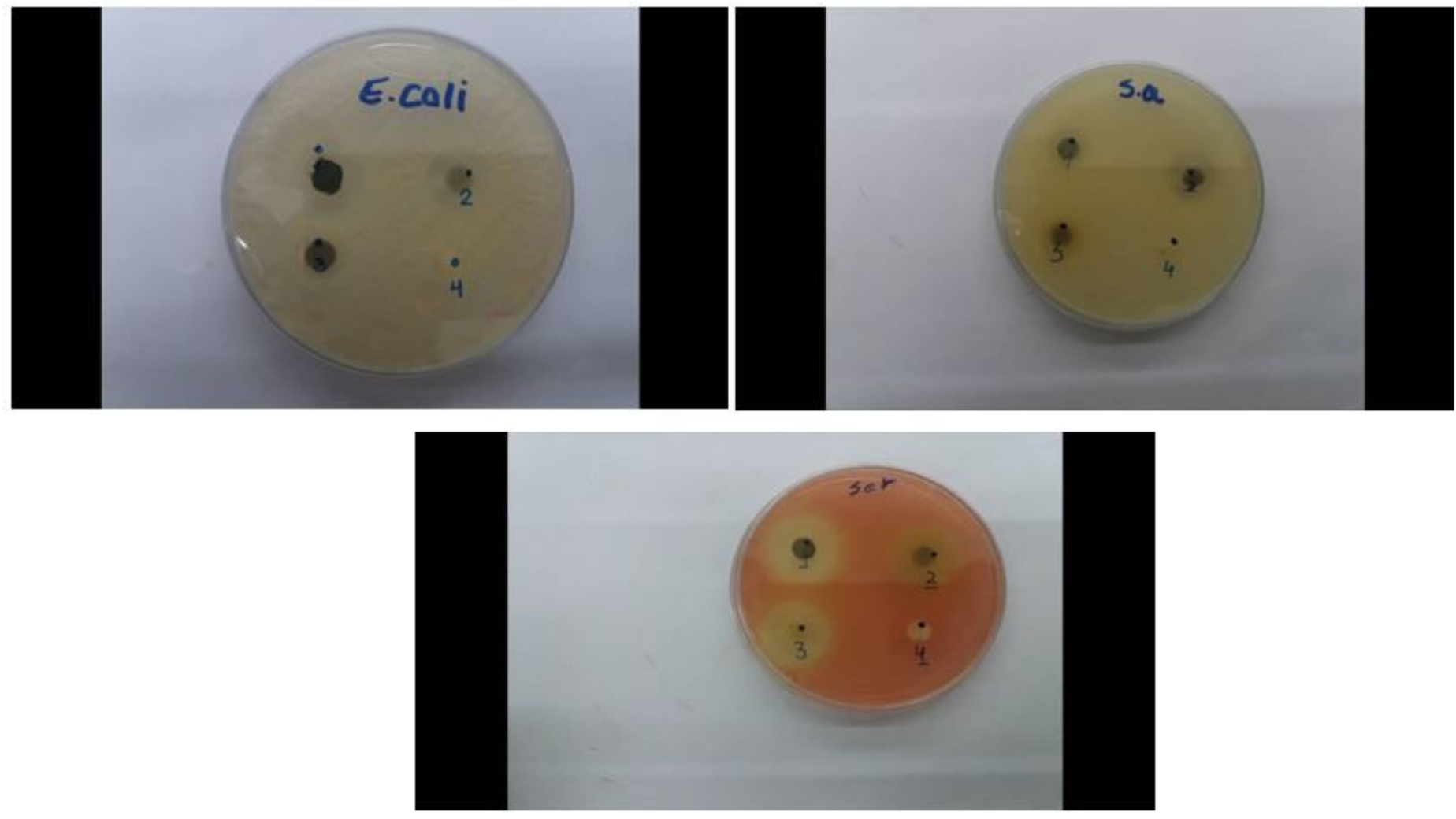
Figure 15

Antibacterial activity of $\mathrm{Mn}$ supported nano catalyst

\section{Supplementary Files}

This is a list of supplementary files associated with this preprint. Click to download.

- Table2a.jpg

- Table2b.jpg 